\title{
Ammonia Gas Transport and Reactionsin Unsaturated Sediments: Implications for Use as an Amendment to Immobilize Inorganic Contaminants
}

\author{
L.Zhong*, J.E. Szecsody, M.J. Truex, M.D. Williams, Yuanyuan Liu \\ Pacific Northwest National Laboratory P.O. Box 999, Richland, WA 99354
}

* Corresponding author: E-mail: lirong.zhong @ pnnl.gov; phone: 509-371-7101; fax: 509-3717174.

\begin{abstract}
Use of gas-phase amendments for in situ remediation of inorganic contaminants in unsaturated sediments of the vadose zone may be advantageous, but there has been limited development and testing of gas remediation technologies. Treatment with ammonia gas has been studied and has a potential for use in treating inorganic contaminants (such as uranium)because it induces a high pore-water $\mathrm{pH}$, causing mineral dissolution and subsequent formation of stable precipitates that decrease the mobility of some contaminants.For field application, further knowledge of ammonia transport in porous media and the geochemical reactions induced by ammonia treatmentis needed. Laboratory studies were conducted to support calculations needed for field treatment design, to quantify advective and diffusive ammonia transport in unsaturated
\end{abstract}


sediments, to evaluate inter-phase (gas/sediment/pore water) reactions, and to study reactioninduced pore-water chemistry changes as a function of ammonia delivery conditions such as flow rate, gas concentration, and water content.Uranium-contaminated sediment was treated with ammonia gas to demonstrate U immobilization. Ammonia gas quickly partitions into sediment pore water and increases the $\mathrm{pH}$ up to 13.2. Injected ammoniagas advection frontmovement can be reasonably predicted by gas flow rate and equilibrium partitioning. The ammoniagas diffusion rate is a function of the water content in the sediment. Sodium, aluminum, and silica pore-water concentrations increase upon exposure to ammonia and then decline as aluminosilicates precipitate when the $\mathrm{pH}$ declines due to buffering. Up to $85 \%$ of the water-leachable $\mathrm{U}$ was immobilized by ammonia treatment.

Keywords: ammonia; transport; unsaturated sediment; immobilization; diffusion, inorganic contaminants.

\section{Introduction}

In situ remediation of inorganic contaminants in unsaturated sediments of the vadose zone is still in an emerging stage of development [1]. Delivery of aqueous-phase amendments to the vadose zone can be problematic due to mobilization of untreated contaminants and limited distribution[e.g. 2, 3]. Use of gas-phase delivery may be advantageous in the vadose zone, but there has been limited development and testing of gas treatment technologies [e.g. 4, 1]. Treatment with ammonia $\left(\mathrm{NH}_{3}\right)$ gas has been studied and has a potential for use in treating inorganic contaminants (such as uranium) by creating stable precipitates that limit the mobility of inorganic contaminants [5]. Using uranium as a specific example, Figure 1 depicts the three primary elements of treatment by ammonia gas. When a gas containing ammonia vapor is 
injected into an unsaturated porous medium, a large percentage of the ammonia partitions into the pore water due to the low Henry's Law constant (a dimensionless value of about $6.5 \times 10^{-4}$ ) of ammonia (Step 1,Figure 1). For example, a $5 \%$ by volume ammonia vapor produces an equilibrium pore-water concentration of about $3 \mathrm{M}$ ammonia. Self-dissociation of ammonia at this concentration results in an increase in the pore water $\mathrm{pH}$ from initially around $\mathrm{pH} 8$ to about $\mathrm{pH} 11.5[6,5]$.Ion exchange and mineral dissolution (including silicate dissolution) is caused by the caustic pH (Step 2, Figure 1) [6,5]. With high total dissolved solids, precipitates start to form, especially as the $\mathrm{pH}$ is buffered back toward neutral. The precipitates may incorporate uranium (e.g., forming sodium boltwoodite) or may form compounds such as quartz, chrysotile, calcite, diaspore, and hematite that could coat uranium already precipitated or adsorbed on the sediment surface (Step 3, Figure 1) [7, 6, 5]. The goal of the dissolution and re-precipitation process is to create uranium precipitates or coatings that render uranium less mobile than before treatment.These mineral dissolution and precipitation principles are also applicable to other inorganic contaminants in the vadose zone.

Studies on several fundamental aspects of uranium treatment using ammonia gas [5] and the application of ammonia gas for technetium immobilization [8] have been reported. When ammonia gas was injected into vadose zone sediments, a series of geochemical reactions, including mineral dissolution and precipitation, were observed. These reactions resulted in an electrical resistivity response in the pore water, which can be utilized to monitor the spreading of the gas [5]. Treatment using ammonia gas in combination with hydrogen sulfide $\left(\mathrm{H}_{2} \mathrm{~S}\right)$ gas has been shown to effectively immobilize technetium in vadose zone sediments [8]. Other studies have shown that treatment ofwater-saturated sediments with alkaline solutions induced similar 
mineral dissolution reactions. In two studies using the same sediments used in this study, montmorillonite, muscovite, kaolinite, biotite, and magnetite were partially dissolved, resulting in high silica, aluminum, sodium, and iron concentrations $[9,10]$.

However, deploying the ammonia technology in the field for treatment of uranium or other inorganic contaminants requiresfurther knowledge about ammonia transport and the geochemical reactions induced by ammonia treatment.Laboratory studies were conducted to support calculations needed for field treatment design, to quantify advective and diffusive ammonia transport in unsaturated sediments, and to evaluate pore-water chemistry changes as a function of ammonia delivery conditions. The study included a series of batch tests of ammonia partitioning into bulk water or pore water. Batch tests were also conducted to provide baseline data for porewater chemistry changes induced by ammonia addition.Gas injection and flow tests were carried out in soil columns and radial wedgeflow cell configurations to study the ammonia advection and resulting reactions under differing sediment water content values, ammonia gas concentrations, gas injection flow rates, and variations in physical heterogeneities. Column and pseudo twodimensional (2D) flow cell tests were also conducted to evaluate ammonia diffusion as a function of sediment water content and sediment heterogeneity.

\section{Materials and Methodology}

\subsection{Materials}

Liquefied anhydrous pure ammonia was used as the gas source to prepare ammonia-innitrogen gas mixtures at $\mathrm{NH}_{3}$ concentrations ranging from $0.1 \%$ to $100 \%$.Ultrapure nitrogen gas 
was used for dilution. Uncontaminated sediments collected from the Hanford formation (sand) and from the Cold Creek unit(silty sand) at the U.S. Department of Energy'sHanford Site (Washington, USA)were used as the porous media. Hereafter, the Hanford formation and Cold Creek unit sediments are referred as "sand" and "silty sand", respectively. These sediments have low natural uranium concentration levels $(<2 \mu \mathrm{g} / \mathrm{g})$. Sediments were sieved to remove pebbles with grain size larger than $4 \mathrm{~mm}$. The grain size and mineralogydetermined using X-ray diffractionof the sedimentsare listed in Table 1.

Sediments were prepared for batch, column, and 2D wedge experiments with specific water contents to either approximate field conditions (averaging $4 \%$ by weight) or to evaluate $\mathrm{NH}_{3}$ gas partitioning (at various water content percentages). Hanford Site groundwater with 0.08 $\mu \mathrm{g} / \mathrm{L}$ uranium was mixed with the natural sediment to achieve the desired water contents.This groundwater generally has high carbonate concentrations[12].

\subsection{Experimental Setup and Procedures}

\subsubsection{Batch tests}

To quantify the rate and extent of ammonia gas partitioning into bulk water, $\mathrm{NH}_{3}$ at concentrations of $0.1 \%, 1.0 \%, 5 \%, 10 \%, 30 \%$, and $100 \%(\mathrm{v} / \mathrm{v})$ was bubbledinto a 100 mLaliquot of deionized water (DIW) at a gas flow rate of $20 \mathrm{~mL} / \mathrm{min}$., while the container holding the water was open to the atmosphere. The $\mathrm{pH}$ and electrical conductivity (EC)of the water was monitored over time.

To study the ammonia-pore water interaction, $3 \mathrm{~g}$ of the sand sediments with water contents of $1,4,8$, and $16 \mathrm{wt} \%$ wereeach placed into separate $50-\mathrm{mL}$ vials. A $250 \mathrm{~mL}$ quantity of ammonia gas at $10 \% \mathrm{v} / \mathrm{v}$ concentration was introducedinto the vialsto replace the air over the 
sediment.The vials were then sealed with caps. Samples of sediments with pore water were taken at time intervals between $1 \mathrm{hr}$. and 8000 hours by sacrificing a vial at each sampling time. DIW was then added to the sediment samples to dilute the pore water, and the $\mathrm{pH}$ and $\mathrm{Ca}^{2+}, \mathrm{Na}^{+}$,

$\mathrm{Si}, \mathrm{Al}^{3+}, \mathrm{Fe}^{3+}, \mathrm{Mg}^{2+}$ concentrations were determined, accounting for dilution. Sediment and $\mathrm{NH}_{3}$ interaction experiments were also conducted with the sediments packed in stainless steel columns to evaluate the $\mathrm{NH}_{3}$ gas treatment at sediment/pore volume ratiossimilar to that under field conditions.After packing, ammonia gas at desired concentrations was injected through the sediment pack with a predetermined volume. The column was then sealed. Sediment samples were taken at time intervals between $168 \mathrm{hr}$. and8760 hr. (1 week and $1 \mathrm{yr}$.)to determine the $\mathrm{pH}$ of the pore water and the $\mathrm{Ca}^{2+}, \mathrm{Na}^{+}, \mathrm{Si}, \mathrm{Al}^{3+}, \mathrm{Fe}^{3+}, \mathrm{Mg}^{2+}$ concentrations in pore water. The change in the concentrations of these ions reveals the mineral dissolution and precipitation.

\subsubsection{Column diffusion tests}

For the 1D diffusion column study, sand and silty sand sediments were packed into PVC pipes with a $1.25 \mathrm{~cm}$ inside diameter (ID) and varied length. A total of 12 columns in 3 groups were packed.Four $100 \mathrm{~cm}$-long columns (Group 1; columns G1-1, -2, -3, -4) were packed withthe sand at 2.0wt\% water content; four $50 \mathrm{~cm}$-long columns (Group 2; columns G2-1, -2, -3, -4) were packed with thesilty sand at $8.7 \mathrm{wt} \%$ water content; and four $25 \mathrm{~cm}$-long columns(Group 3; columns G3-1, -2, -3, -4) were packed with thesilty sand at $13.0 \mathrm{wt} \%$ water content. Each column was then connected to a 26 Lbag holding $5 \% \mathrm{v} / \mathrm{v} \mathrm{NH} 3$ gas. Plastic tubing equipped with a valve was used for the connection. The valve was opened to start the diffusion test.At each sample collection time $(72,192,336$, and $672 \mathrm{hr}$.), a column from each group was disassembled and sediment samples along the length of the column were taken to analyze for the ammonia concentrations in pore water. 
The total mass of $\mathrm{NH}_{3}$ at $5 \% \mathrm{v} / \mathrm{v}$ in the $26 \mathrm{Lbag}$ is 0.0537 moles. Using the average sediment bulk density $\left(1.696 \mathrm{~g} / \mathrm{cm}^{3}\right)$ and the known water content in the columns, the amount of $\mathrm{NH}_{3}$ needed to partition into pore water to achieve equilibrium was calculated to be $0.0129,0.0281$, and 0.0210 moles per column for Groups 1,2, and 3, respectively. Therefore the amount of ammonia in the bag is sufficient to achieve pore water equilibrium in each of the columns.

Forthe 2D diffusion study, a cylindrical stainless steel vessel with $7.62 \mathrm{~cm}$ (3 inch) ID and $10.16 \mathrm{~cm}$ (4 inch) length was used to heterogeneously pack thesand andsilty sand.The sediment was packed into the columns in two transversely heterogeneous patterns (2D-P1 and 2D-P2), as shown in Figure2. The water content of each zone is listed on Figure 2. A flow distribution plate was placed in each end of the vessel to evenly distribute the gas injection and collect the gas effluent. A $26 \mathrm{~L}$ volume of $5 \% \mathrm{v} / \mathrm{v}$ ammonia gas was pumped through the soil column at flow rate of $2.5 \mathrm{~mL} / \mathrm{min}$. using a peristaltic pump(Cole Palmer Instrument Company, Chicago, Illinois) for a duration of one week. The vessel was then disassembled and sediment samples were collected to measure the concentrations of dissolved ammonia and EC of the pore water. The sample locations were at predetermined axial distances from the gas inlet and a range of transverse distances from the sand/silty sand interface into the silty sand. 


\subsubsection{Column tests on gas advection and gas-sediment interaction}

Column tests were designed and performed to study the $\mathrm{NH}_{3}$ transport in sediment under vadose zone conditions and to investigate the reaction of ammonia with sediments and pore water. Sand with the desired water content was packed into columns with anID of $1.25 \mathrm{~cm}$ and a length between 1.5 and $9.1 \mathrm{~m}$ ( 5 and $30 \mathrm{ft}$.). Ammonia gas with concentrations between 5 and $100 \% \mathrm{v} / \mathrm{v}$ was injected through the columns. Because the ammonia gas and water interaction is an exothermic process, causing temperature increase, the axial temperature profile in the sediment columnwas measured to monitor the progression of the reaction front down the length of the soil column. In some tests, the $\mathrm{NH}_{3}$ concentrations in the axial locations across the column were measured during the gas flushing. After termination of gas flow, columns were taken apart and sediment samples were collected at intervals alongthe axis of the soil column for assay of sediment water content, as well as $\mathrm{pH}, \mathrm{EC}$, and ion concentrations of the pore water.

To study theadvance of the reaction front as a function of the $\mathrm{NH}_{3}$ gas flow rate, injection rates were varied to achieve gas velocitybetween $11 \mathrm{~cm} / \mathrm{min}$ and $1177 \mathrm{~cm} / \mathrm{min}$, corresponding to injection rate of $20 \mathrm{~mL} / \mathrm{min}$. and $2119 \mathrm{~mL} / \mathrm{min}$., respectively. These rates were chosen such that the flow rates in the column would coverthe rates that would occur inafield-scale application that is being prepared at the Hanford Site with gas flow rate of $48 \mathrm{~cm} / \mathrm{min}$ at the location $0.5 \mathrm{~m}$ away from the injection well.The sediment had $2 \mathrm{wt} \%$ water content in all columns in this set of tests.

\subsubsection{Radial wedge injectiontests}

To approximate a field injection where the gas velocity decreases with radial distance from the injection well, anisosceles triangular wedge system was built in the laboratoryto simulate a portion of a radial flow field. This wedge flow system has dimensions of $50 \mathrm{~cm}$ high, 
$122 \mathrm{~cm}$ for the long sides and $50 \mathrm{~cm}$ for the short side (i.e. the effluent end during gas injection). The flow cell covers a radial angle of 23 degrees. The dimensions of this wedge flow system enables theemplacement of heterogeneities and the evaluation of gas reactivity as the velocity decreaseswith radial distance from the injection end.Four layers of sediment with differing grain sizes(sand and silty sand) and water contentswere packed into the radial flow system to evaluate $\mathrm{NH}_{3}$ gas advection and diffusion in a heterogeneous system. In addition, eight silt lenses and eight fine-sand lenses with initial water contents ranging from $1 \%$ to $16 \mathrm{wt} \%$ were distributed in the sand layers. Details of the packing are shown in the pictures presented in the Results and Discussion section.

Pure ammonia gas was injected at the wedge's inlet through a vertical perforated well at a flow rate of $2100 \mathrm{~mL} / \mathrm{min}$., simulating field injection. Theexperiment was ended beforethe reaction front reached the effluent end to allow characterization of the front. The entire wedge flow system was placed in a fume hood during the experiment. When gas injection was completed, sediment samples were taken from the layers at different distances from the injection well and from the lenses. Samples were assayed for sediment water content, as well as the $\mathrm{pH}$ and ECof the pore water.

\subsubsection{Uranium Immobilization and Leaching}

To demonstrate uranium immobilization by ammonia gas treatment in the laboratory scale, uranium-contaminated sediment from the 200 Area of the DOE Hanford Site was used to conduct the gas treatment tests. This sediment had a uranium concentration of $55 \mathrm{mg} / \mathrm{kg}$ [13]. The sediment was packed into $1.5 \mathrm{~cm}$ ID by $15 \mathrm{~cm}$ long stainless steel columns and treated with $5 \%$ and $15 \% \mathrm{v} / \mathrm{v} \mathrm{NH}_{3}$ gas for 500 hours. Afterwards, air was flushed through the treated 
columns. The columns were then sealed and left undisturbed for 26000 hours (about 3 years) to allow sufficient time for mineral precipitation. The sediment columns were leached for uranium using clean Hanford groundwater to evaluate the efficacy of $U$ immobilization by comparing the U leaching results from the gas-treated soil columns with untreated sediments. Aqueous U(VI) in the column effluent was measured by laser-induced kinetic phosphorimetry [14].

\subsubsection{Numerical Simulation}

One dimensional gas diffusion column experiments (Section 2.2.2) were simulated using the Subsurface Transport Over Multiple Phases (STOMP) simulator [15]. These diffusion-only STOMP simulations included 1-D diffusion in the gas phase, equilibrium gas-pore water partitioning (based on Henry's Law), and 1-D diffusion in pore water.Ammonia properties used for these simulations included a dimensionless Henry's Law coefficient of $6.5 \times 10^{-4}$, a gas diffusion coefficient of $2.28 \times 10^{-5} \mathrm{~m}^{2} / \mathrm{s}$ [16], and an aqueousdiffusion coefficient of $1.86 \times 10^{-9} \mathrm{~m}^{2} / \mathrm{s}$ [17]. Additional parameters for the simulations included solute and gas tortuosity.

Initially, tortuosity factors were calculated using theMillington and Quirktortuosity model [18] but needed to be adjusted due to the poor fit with the experimental data. Chou et al. [19] evaluated a number of empirical models for aqueous tortuosity factors on three different test soils (sand, sandy clam loam, and clay) and found that the Millington and Quirktortuosity model [18]had the highest Root Mean Square Error (RMSE). The study concluded that the Mullins and Sommer model[20] had the lowest RMSE for sands, therefore the solute tortuosity factor for these 1-D column simulations were calculated based on the Mullins and Sommer [20] equation using the parameters from Chou et al. [19]. Calculated solute tortuosity factors were $1.0 \times 10^{-4}(\mathrm{a}$ nominal low value), $8.4 \times 10^{-4}$, and $4.5 \times 10^{-3}$ for the G1, G2, and G3 experiments, respectively 
(in order of increasing water contents). Gas tortuosity factors were manually adjusted to the fit the distal portion of the experimental data. Final values for gas tortuosity factors were 0.05 , 0.15 , and 0.12 for G1, G2, and G3, respectively. While gas tortuosity factors should decrease with increasing water content, differences in the sediment type and column packing could explain the different trend for the fitted gas tortuosity values between the sand (G1) and silty sand (G2 and G3). For comparison, gas tortuosity factorscalculated using theMillington and Quirk model [18] are 0.56, 0.21, and 0.079 for columns G1, G2, and G3,

The simulations used a 0.25 -cm grid spacing for the length of each column, with a no-flow boundary at one end and a Dirichlet boundary condition (with constant ammonia concentration) at the other end for the ammonia gas concentration. Water saturations were specified for initial conditions to match the values for the 3 groups $(\mathrm{G} 1, \mathrm{G} 2, \mathrm{G} 3)$ of experiments (discussed earlier).The initial ammonia concentrations in the model domain were set to zero.

\subsection{Analytical Methods}

\subsection{1. $\mathrm{NH}_{3}$ concentration measurement}

Two different methods were applied to measure ammonia gas concentrations. The first method used a Perkin Elmer ultraviolet (UV) absorbance detector using absorbance at a wave length of $204 \mathrm{~nm}$. A 10-cm long,30 mL volumecylindrical cell was used to hold the gas sample. Ammonia gas concentrations were diluted to below $0.5 \% \mathrm{v} / \mathrm{v}$ to maintain absorbance linearity (< 1.0 absorbance unit). This analysis method uses only a small volume of gas; however, it took about $10 \mathrm{~min}$. to completeone sample analysis. The secondammonia gas analysis methodused a Drager gas sampler and colormetric tubes designed for $\mathrm{NH}_{3}$ gas of concentration less than $10 \%$. A $100 \mathrm{~mL}$ sample volume was needed for this method. The second method required about 20 
seconds for each measurement and was used for rapid measurements during column and wedge flow experiments.

\subsubsection{Pore water specific conductance measurement}

A specific conductance meter (Yellow Springs Instrument, Yellow Springs, OH, USA) equipped witha flow-through electrode (Microelectrodes, Bedford, NH, USA) was used to measure the $\mathrm{EC}$ of the pore water in sediment samples taken after the gas treatment experiments. Because the total mass of pore water was small in each sediment sample, $3 \mathrm{~mL}$ of DIW was added to the sample to ensure that the water volume was sufficient for the EC measurement. Approximately $1 \mathrm{~mL}$ of water was flushed through the flow-through electrode to get the EC measurement, while the minimum volume required for measurement is $20 \mu 1$. The pore water electrical conductivity was back calculated from the dilution factor, which was based on the moisture content of the sample and the added water volume.

\subsubsection{Pore water ions and dissolved ammonia concentration analyses}

Aqueous cation and element $\left(\mathrm{Ca}^{2+}, \mathrm{Mg}^{2+}, \mathrm{Na}^{+}, \mathrm{Fe}^{3+}, \mathrm{Si}\right.$, and $\left.\mathrm{Al}^{3+}\right)$ concentrations in the sediment pore water were measured using an inductively coupled plasma optimal emission spectrometer (ICP-OES, Perkin-Elmer Optima 2100DV). Aqueous ammonia was measured colorimetricallyusing HachMethod 10031.

To determine the water content in sediment, the sediment was dried in an oven at $80^{\circ} \mathrm{C}$ for 24 hours. The weight difference between wet and dry sample was used to calculate the water content.

\section{Results and Discussion}




\section{1. $\mathrm{NH}_{3}$ Gas Partitioning intoSediment Pore Water}

Calculations to support ammonia treatment design are based on ammonia partitioning behavior and the properties of the subsurface within the treatment zone. As a simplification for scoping-level ammonia delivery field design, pure water and ideal conditions with respect to gasliquid partitioning and solute behavior are assumed. Under these conditions, ammonia in the gas-phase partitions to the pore water based on the value of the dimensionless Henry's Law constant $\left(\mathrm{H}_{\mathrm{NH} 3}\right)$ where Henry's Law is defined in Equation 1.

$$
\mathrm{H}_{\mathrm{NH} 3}=\left[\mathrm{NH}_{3}\right]_{\mathrm{gas}} /\left[\mathrm{NH}_{3}\right]_{\mathrm{aq}}
$$

The temperature-dependent Henry's Law constant for ammonia $\left(\mathrm{H}_{\mathrm{NH} 3 \mid \mathrm{T}}\right)$ can be calculated from Equation 2 [21] using the subsurface temperature $(\mathrm{T})$ in Kelvin.

$$
\left.\mathrm{H}_{\mathrm{NH} 3}\right|_{\mathrm{T}}=1 /\left(\mathrm{e}^{(-9.70+4092 / \mathrm{T})}\right)
$$

This Henry's Law constant in units L-atm/mole of can be converted to a dimensionless value by dividing the value by $\mathrm{R}$ (in units of $\mathrm{L}-\mathrm{atm} / \mathrm{mole}-\mathrm{K}$ ) and the temperature (degrees Kelvin). In the pore water itself, the equilibrium of the ammonia-ammonium system in the selfdissociation reaction $\left(\mathrm{NH}_{3}+\mathrm{H}^{+} \quad \mathrm{NH}_{4}^{+}\right)$is described by Equation 3 in terms of the dissociation

constant $\left(\mathrm{K}_{\mathrm{NH} 3 \mid \mathrm{T}}\right)$ and aqueous concentrations of the species involved.

$$
\left.\mathrm{K}_{\mathrm{NH} 3}\right|_{\mathrm{T}}=\left[\mathrm{NH}_{3}\right]_{\mathrm{aq}}\left[\mathrm{H}^{+}\right] /\left[\mathrm{NH}_{4}^{+}\right]
$$

Clegg and Whitfield (1995) [22] provide an equation describing the temperature dependence of the dissociation constant $\left(\left.\mathrm{K}_{\mathrm{NH} 3}\right|_{\mathrm{T}}\right)$, as shown in Equation 4.

$$
\ln \left(\left.\mathrm{K}_{\mathrm{NH} 3}\right|_{\mathrm{T}}\right)=\ln \left(\mathrm{K}_{\mathrm{NH} 3 \mid 298.15}\right)+((52252 / \mathrm{R}) \times(1 / 298.15-1 / \mathrm{T}))
$$


In Equation 4, R is the gas constant $\left(8.31446 \mathrm{~J} \cdot \mathrm{mol}^{-1} \cdot \mathrm{K}^{-1}\right)$, T is temperature in Kelvin, and $\mathrm{K}_{\mathrm{NH} 3 \mid 298.15}$ is $5.69 \times 10^{-10} \mathrm{M}$.

Interphase partitioning and the self-dissociation reaction are combined to determine the amount of aqueous ammonia. A charge balance for the dissociation reaction is written as shown in Equation 5 for the ammonium ion and ionized water components.

$$
\left[\mathrm{NH}_{4}^{+}\right]+\left[\mathrm{H}^{+}\right]=\left[\mathrm{OH}^{-}\right]
$$

The ionization constant for water $\left(\mathrm{K}_{\mathrm{H} 2 \mathrm{O}}\right)$, representing the product of $\mathrm{H}^{+}$and $\mathrm{OH}^{-}$concentrations, can be identified from tabulated values as a function of temperature (http://www.kayelaby.npl.co.uk/chemistry/3_9/3_9_4.html) and has a value of 6.71 $10^{-15}$ at $20^{\circ} \mathrm{C}$. This ionization constant and relationship (written as $\left[\mathrm{H}^{+}\right]=\mathrm{K}_{\mathrm{H} 2 \mathrm{O}} /\left[\mathrm{OH}^{-}\right]$) can be substituted into Equation 3, which (after rearrangement) results in Equation 6.

$$
\mathrm{K}_{\mathrm{H} 2 \mathrm{O}} /\left.\mathrm{K}_{\mathrm{NH} 3}\right|_{\mathrm{T}}=\left[\mathrm{NH}_{4}^{+}\right] \cdot\left[\mathrm{OH}^{-}\right] /\left[\mathrm{NH}_{3}\right]_{\mathrm{aq}}
$$

Substituting $\left[\mathrm{H}^{+}\right]=\mathrm{K}_{\mathrm{H} 2 \mathrm{O}} /\left[\mathrm{OH}^{-}\right]$into Equation 5 and then substituting the resulting equation into Equation 6 yields Equation 7, which can be used to solve for [ $\left.\mathrm{OH}^{-}\right]$using knowledge of the coefficient values and the computed $\left[\mathrm{NH}_{3}\right]_{\text {aq }}$ from Equation 1 (based on $\left[\mathrm{NH}_{3}\right]_{\text {gas }}$ as an input).

$$
\mathrm{K}_{\mathrm{H} 2 \mathrm{O}} /\left.\mathrm{K}_{\mathrm{NH} 3}\right|_{\mathrm{T}}=\left(\left[\mathrm{OH}^{-}\right]^{2}-\mathrm{K}_{\mathrm{w}}\right) /\left[\mathrm{NH}_{3}\right]_{\mathrm{aq}}
$$

Once $\left[\mathrm{OH}^{-}\right]$has been determined, $\left[\mathrm{NH}_{4}^{+}\right]$can be calculated from Equation 6 and the $\mathrm{pH}$ can be calculated from the ionization equation for water, presented above.This approach provides a means to calculate a theoretical total amount of ammonia and ammonium in solution for an input ammonia gas concentration. Because of the geochemical reactions that cause speciation of 
ammonia within the aqueous phase, the movement of ammonia vapor through the partially water-saturated porous medium is a function of a total-species partitioning coefficient $\left(\left.\mathrm{K}_{\mathrm{NH} 3}\right|_{\text {total }}\right)$, which can be calculated with Equation 8 .

$$
\left.\mathrm{K}_{\mathrm{NH} 3}\right|_{\text {total }}=\mathrm{NH}_{3(\mathrm{~g})} /\left(\left[\mathrm{NH}_{3}\right]+\left[\mathrm{NH}_{4}^{+}\right]\right)
$$

The total ammonia required to meet the above-calculated equilibrium loading can be determinedbased on the amount of water within the targeted treatment zone. The amount of water in this zone can be estimated from the sediment moisture content.

Figure 3 shows the calculated mass fraction of $\mathrm{NH}_{3}$ in gas atmultiple sediment water content values. At $4 \mathrm{wt} \%$ water content (a nominal value for the Hanford vadose zone), $0.27 \%$ of the $\mathrm{NH}_{3}$ mass remains in the gas phase and $99.73 \%$ of the mass partitions into water.

As an example, Table 2 shows the calculated ammonia and $\mathrm{pH}$ values in pore water as a function of ammonia gas concentration for equilibrium conditions at $20^{\circ} \mathrm{C}$. The calculated $\mathrm{pH}$ resulting from ammonia gas partitioning to water (Table 2) was closely achieved in experiments by bubbling ammonia gas at the same concentration through $100 \mathrm{~mL}$ deionized water at gas flow rate of $20 \mathrm{~mL} / \mathrm{min}$. for 10 minutes (Figure 4), indicating that equilibrium was achieved rapidly. However, ammonia delivery conditions in the field may limit the ability to achieve these equilibrium values.

\subsection{Ammonia Advective Flow in Unsaturated Sediment}


Ammonia partitioning significantly controls the gas movement in unsaturated sediment. For ideal equilibrium partitioning, ammonia gas injected into the vadose zone sediment would partition into the pore water to reach an equilibrium concentration upstream of the ammonia gas front. Within this region, the gas mixture has the ammonia concentration of the influent. A sharp front of pore-water ammonia concentration and associated pore water $\mathrm{pH}$ would be observed under such ideal equilibrium conditions. Experiments in 6-m-long columns at varying gas injection rates all resulted in a $\mathrm{pH}$ profile within the column indicative of reaching nearequilibrium $\mathrm{pH}$ up to the ammonia gas front, downstream of which the $\mathrm{pH}$ was sharply lower (Figure 5). Ammonia gas front retardation relative to the gas flow rate was $202 \pm 31$ in these experiments. High gas velocities may overcome partitioning-controlled behavior. For instance, ammonia gas front retardation relative to the gas flow rate was 363 in a similar column test with measured ammonia mixture gas front advection rate of $2200 \mathrm{~cm} / \mathrm{min}$. A higher retardation of the ammonia gas front would be observed if equilibrium partitioning were not immediately achieved and a portion of the added ammonia mass moved downgradient in the gas phase without partitioning. In that case, more pore volumes (PV) of gas would need to be supplied to meet equilibrium conditions associated with definition of the ammonia gas front. High gas velocity conditions would likely only exist very near an injection well because velocity decreases rapidly under radial flow conditions. Because of the strong dependence on equilibrium partitioning, ammonia gas front advection is faster in low moisture content zones compared to higher moisture content zones for the same gas velocity [7]. Ammonia gas front retardation estimates are very sensitive to the sediment moisture content and porosity. For instance, the computed retardation for sediment moisture content values of 2, 4, and $6 \mathrm{wt} \%$ are 220, 510, and 910, respectively, assuming a porosity of $30 \%$. Retardation estimates for a sediment moisture content 
value of $4 \%$ and 25,30 , and $35 \%$ porosity are 720,510 , and 380 , respectively. Thus, an approximate ammonia gas front retardation factor can be estimated for field applications, but variations of the actual factor in the targeted treatment zone should be expected based on spatial variations in moisture content and porosity.

There are other factors that can potentially affect the retardation and migration of ammonia gas in the sediment. These factors include the carbon dioxide gas $\left(\mathrm{CO}_{2}\right)$ partitioning into pore water, redox reaction of ammonia gas, and microbial consumption of $\mathrm{NH}_{3}$ gas.

Because the laboratory tests were conducted in closed systems, the $95 \% \mathrm{~N}_{2} / 5 \% \mathrm{NH}_{3}$ gas mixture injection flushed out the gases originally in the system, therefore $\mathrm{CO}_{2}$ to liquid partitioning would not occur. At field scale withan uniform system, air would generally not be near the $\mathrm{NH}_{3}$-treated sediment since it will be flushed out due to the high number of pore volumes of $5 \% \mathrm{NH}_{3}-95 \% \mathrm{~N}_{2}$ gas mixture injection. However, in layered systems, air (containing $\mathrm{CO}_{2}$ ) in low-permeability zones would be poorly displaced by the gas flushing and could be near the high-permeability zones of alkaline pore water resulted from $\mathrm{NH}_{3}$-treatment. Therefore, some $\mathrm{CO}_{2}$ in the air could partition (and neutralize) the nearby $\mathrm{NH}_{3}$-treated pore water which may affect the migration of $\mathrm{NH}_{3}$ to some extent.

In one of our previous studies, it has been demonstrated that the ammonia gas loss due to reaction with sediment was minimal and the ammonia consumption by microbes was negligible [8].

Of interest for monitoring of the ammonia advection front in the laboratory tests or in the field, there isa significant temperature increase in the pore waterbecause the $\mathrm{NH}_{3}$ gas to liquid 
partitioning reaction is rapid and exothermic. Injection of $100 \% \mathrm{NH}_{3}$ gas into a sediment column resulted in an increase in temperature by as much as $30^{\circ} \mathrm{C}$ (Figure 6) as the ammonia gas front passed a monitoring location. For injection at a 5\% ammonia concentration, the temperature rise was less significant (similar column tests showedan increase on the order of $4^{\circ} \mathrm{C}$.Temperature measurement has been successfully applied to monitor the progress of vadose zone remediation, in a case of process (desiccation) causing temperature to decrease[23]. Field temperature monitoring during ammonia injection can potentially be applied to locate the $\mathrm{NH}_{3}$ advection front.

\section{3. $\mathrm{NH}_{3}$ Gas Diffusion}

In uniform sediment, the gas diffusion rate is a function of water content and the related partitioning from the gas to liquid phase. Figure 7 shows the distance from the columninlet tothe $0.1 \mathrm{M}$ ammonia pore-water concentration front (i.e., a front where the pore-water $\mathrm{pH}$ is over 11 , Table 2)over time as a result of diffusion from a 5\% ammonia gas boundary condition. A generally linear relationship between the diffusion distance and time was approximated for data collected starting about 700 hours after the start of the experiment, although some decline in the rate would be expected with distance from the constant-gas-concentration boundary condition. The nominal0.1 M ammonia-concentration front velocity from this linear approximation was calculated to be about $0.05,0.03$, and $0.02 \mathrm{~cm} / \mathrm{hr}$ for the $2 \%$ water sand, $8.7 \%$ water silty sand, and $13 \%$ water silty sand, respectively, as shown by the straight dotted line in Figure 7. 
The fitted trend lines in Figure 7 did not go through origin point, but instead had y-axisintercepts at about $8.4 \mathrm{~cm}, 6.3 \mathrm{~cm}$, and $4.8 \mathrm{~cm}$ for the $2 \%$ water sand, $8.7 \%$ water silty sand, and $13 \%$ water silty sand, respectively. This observation indicates that the diffusion front traveled faster at the beginning of the experiment near the inlet. This result can be attributed to initially high concentration gradients near the constant-gas-concentration boundary condition and to the laboratory test artifact of a slightly positive gas pressure initiallyin the bags used to provide the $\mathrm{NH}_{3}$ gasboundary condition.About the same amount of $\mathrm{NH}_{3}$ would have been advected into each column from the bags by pressure when the valves were opened to start the diffusion tests. With lower sediment water content, the $0.1 \mathrm{M}$ ammonia front would travel further into the column because less water per linear column distance is available for partitioning of the ammonia. Therefore the intercept in Figure 7 is larger for the column with lower water content.Gas phase tortuosity values are also expected to be lower (i.e. more tortuous) at higher water contents[e.g. 18].

When aqueous and gas tortuosities calculated from the Millington and Quirk model [18]were used in theSTOMP numerical simulations, a poor fit of the experimental data was produced. Therefore, the aqueous tortuosity was calculated using the Mullins and Sommermodel [20] and gas tortuosity values were manually adjusted to fit the distal portions of the experimental data as discussed in Section 2.2.6. The simulated diffusion distance versus time with the adjusted tortuosity is represented on Figure 7 as the slightly curved solid lines.The curvature in the simulation results was less when water content was higher. Overall, a reasonably good match between the experimental data and simulation results was obtained, especially for the higher water content case. The diffusion rates produced from the linear fit to the experimental data are similar to those calculated from the numerical simulation. These rates can be used to 
predict the $\mathrm{NH}_{3}$ diffusion front in the low permeability layers or lenses with known water content and estimated tortuosity in field settings.

In heterogeneous packing pattern 2D-P1 and 2D-P2, 0.0098 and 0.0142 moles $\mathrm{NH}_{3}$, respectively, is needed to saturate the pore water in the sand. The total ammonia massin the injected $26 \mathrm{~L}$ volume of $5 \% \mathrm{v} / \mathrm{v}$ ammonia gas mixture is 0.0537 moles.Although more than enough ammonia was provided to fully saturate the high-permeability lower moisture-content layer (sand) in the experiments, ammonia concentrations decrease with distance from the inlet within this sand packs(Figure 8). Lateral ammonia movement into the surrounding silty sand layers is evident in the observed pattern of ammonia concentrations, with highest concentrations in the layer nearest to the inlet and nearest to sand layer. These results demonstrate the slow advection of ammonia due to partitioning in the pore water and the associated significant diffusion into surrounding low-permeability zones. The diffusion rates obtained in the 1D column experiments (Figure 7) correspond to diffusion distances for a $0.1 \mathrm{M}$ ammonia porewater concentration front of 5 and $3.4 \mathrm{~cm}$ over one week of exposure for the $8.7 \%$ water silty sand, and $13 \%$ water silty sand, respectively. These diffusion distances are consistent with observations of $0.1 \mathrm{M}$ ammonia pore-water concentrations penetrating significantly into the low permeability portions of the 2D experiments in Figure 8 at the inlet end of the column where a boundary condition of high ammonia gas concentration was present for an extended portion of the week-long experiment. As observed, less movement would be expected near the outlet of the 2D experiment where ammonia gas concentrations in the high permeability layer were lower due to partitioning of ammonia during advection. Due to the configuration of the $2 \mathrm{D}$ diffusion experiments, some advection of ammonia into the low permeability zones could also have occurred, especially in the inflow end. 


\subsection{Ammonia Delivery in a Radial Flow System with Heterogeneities}

The heterogeneous packing in the wedge-shaped flow cell is shown in Figure 9. This test was a demonstration of ammonia delivery with both large and small scale heterogeneous features and radial-flow conditions, for which both advection and diffusion may be important to ammonia delivery. Pictures of the front side of the flow system taken at different times (Figure 9c) show the advance of the reaction front. Advection of the front was faster in the sand layers (center) compared with the silt sand layers. A close-יnimageof the reaction front(Figure 8d)shows the formation of larger condensate droplets. These droplets were formed due to the combination of: a) water evaporation and condensation onto the wedge walls due to the exothermic reaction between $\mathrm{NH}_{3}$ gas and pore water; b) a decrease in the liquid viscosity as the ammonia concentration increased[24]; and c) an increase in liquid volume caused by partitioning of $\mathrm{NH}_{3}$ gas into the liquid [25].

A small area near the injection endof the wedge-shaped flow cell showed desiccation of the sediment (Figure 9c). The water content in sediment near the inlet was measured after the experiment and found to be lower, while thewater content in each layer at locations further down gradient from the inlet retained a water content similar to the initial conditions. Desiccation during ammonia treatment would only beexpected in areasclose to the injection well because it requires about 25,000 pore volumes of dry gas to remove $5 \mathrm{wt} \%$ of water from a sediment using dry air [26]. 
The $\mathrm{pH}$ profiles in the low-K (silty sand) and high-K (sand) layers (Figure 10a) identify the location of the reaction front, showing slower $\mathrm{NH}_{3}$ advection in the low-K layer. The $\mathrm{pH}$ in discontinuous lenses (black triangles, Figure 10a) was approximately the same as that in the surrounding high-K sand. Thus, diffusion into these low permeability, higher water content lenses occurred during the ammonia delivery experiment and these zones were not bypassed. After 7 months ofammonia-treated sedimentexposureto air, the sediment pore water $\mathrm{pH}$ had decreased from around 12 to 9.3 (average), as shown in Figure 10b for the high-K layer.

Upon exposure to air, the EC of the pore water (data not shown) also dropped in a pattern similar to the $\mathrm{pH}$ changes over time. This indicates that precipitation occurred in most of the sediments when they were exposed to the air.

\section{5. $\mathrm{NH}_{3}$ Induced Mineral Dissolution and Precipitation}

\subsubsection{Porewater ionsin batch sediments}

Mineral dissolution/precipitation reactions resultingfrom $\mathrm{NH}_{3}$ gas-sediment interactions are indicated by pore water cation and anion concentrations. Alkaline dissolution of sand in water-saturated sediments resulted in high aqueous concentrations of silica, aluminum, and sodium from dissolution of montmorillonite, muscovite, and kaolinite [10], iron from dissolution of biotite and magnetite [9], and other ions from dissolution and desorption. Ammonia gas treatment of the sand sediment at differing initial water content showed cation concentrations that were proportional to the resulting $\mathrm{pH}($ Figure 11). When the sediment water content was lower, the gas treatment induced a higher $\mathrm{pH}$ in the pore water, resulting in higher dissolved cation concentrations.Compared to the ion concentrations in the pore water of untreated 
sediments (with $1 \%$ water content), the dominant aqueous cations produced as a result of $\mathrm{NH}_{3}$ treatment are silica and sodium (Figure $11 \mathrm{a}, \mathrm{e}$ ), similar to previous observations [5].

In a previous study using water-saturated systems, it was shown that the silica concentrations slowly increased for hundreds of hoursto $15 \mathrm{mmol} / \mathrm{L}$, due to slow clay dissolution [10]. In contrast, in low water content sediments, the aqueous silica concentration increased much faster and reached higher concentrations $(100 \mathrm{mmol} / \mathrm{L}$ in $24 \mathrm{~h})$. Silica concentration then slowly decreased over tens to thousands of hours due to buffering. Low water content sediments showed initial aluminum concentrations $(0.8 \mathrm{mmol} / \mathrm{L}$, Figure $11 \mathrm{~b})$ to be nearly the same as watersaturated sediment concentrations[10].This concentration also decreased with time, indicating precipitation. Studies in alkaline-contaminated Hanford sediments indicate that the aluminosilicatecancrinite, zeolite, sodalite, and quartz may precipitate [27, 28, 29, 30, 9].

The pore water concentrations of $\mathrm{Mg}^{2+}$ and total iron decrease rapidly, in less than 100 hours, likely due to metal-hydroxide precipitation. In water-saturated alkaline dissolution of similar Hanford formation sediments, $\mathrm{Mg}^{2+}$ and $\mathrm{Fe}^{3+}$ concentrations were below detection limits, and $\mathrm{Fe}^{2+}$ concentrations were $<0.1 \mathrm{mmol} / \mathrm{L}[10]$. Sodium decreases to some extent and dropped to about half of the initial concentration after a year.

\subsubsection{Pore water ions in column sediments}

Concentrations of $\mathrm{Si}, \mathrm{Al}^{3+}, \mathrm{Fe}^{3+}$, and $\mathrm{Mg}^{2+}$ inpore water of the 6-m (20-ft) columnsediment treated with $5 \% \mathrm{NH}_{3}$ are plotted in Figure 12. $\mathrm{Si}, \mathrm{Al}^{3+}$, and $\mathrm{Fe}^{3+}$ showed the highest concentrations at the inlet of column, because these locations were exposed for the longest duration to high $\mathrm{NH}_{3}$ concentrations (Figure 12a, b, c). The ion concentrations gradually decline 
with axial depth into the column, where the sediment received less gas treatment.

$\mathrm{Mg}^{2+}$ concentration was the highest for the untreated sediment (Figure 12d), which is consistent with what was observed in the batch tests (Figure 11d).

\subsection{Uranium Immobilization}

As described above, ammonia can be distributed in the subsurface and induce sediment dissolution and subsequent precipitation reactions. These processes can result in a decrease in contaminant mobility if the contaminants form precipitates during this process or if surfaceassociated contaminant phases become coated by stable precipitates like aluminosilicates[5]. As an example of this treatment effect, the mass of $\mathrm{U}$ leaching from $\mathrm{NH}_{3}$-treated $\mathrm{U}$-contaminated sediment was significantly less compared to the mass leached from the untreatedsediment (Figure 13).At $220 \mathrm{PV}, 83 \%$ and $85 \%$ of the water leachable $\mathrm{U}$ was immobilized for the $5 \%$ and $15 \%$ ammonia gas treated sediments, respectively. Withmore PV of leaching, additional U mass was released from the untreated sediment while minimal additional uranium mass leached from the treated sediments (Figure 13).

During the leaching, an increase of $U$ concentrations in the effluent were observed when water flow was re-initiated after 1000-h stop flow event at 10 and 50 pore volumes leaching times for the treated sediments. These increases in concentration indicated that either physical or chemical kinetic effects were slowly releasing Uinto the pore water from the treated sediments.

\section{Conclusions}

To better understand the processes and deploy the ammonia treatment technology for remediation of vadose zone uranium and other inorganic contaminants, batch, column, and 
wedge flow cell experiments were conducted to study the ammonia gas transport and reaction. These studies included variations $\mathrm{inNH}_{3}$ concentration, sediment water content, and formation heterogeneity. Uranium contaminant immobilization by $\mathrm{NH}_{3}$ treatment was also demonstrated at the laboratory scale.

Ammonia transport was found to be reasonably predicted based on advective or diffusive gas-phase movement coupled with equilibrium partitioning from the gas to the liquid phase. While some deviation from these predictions occurred, likely due to rate-limited mass transfer from gas to liquid phases, the assumption of equilibrium partitioning is useful for injection design estimates. Theestimated ammonia gas diffusion rate was between 0.05 and $0.02 \mathrm{~cm} / \mathrm{hr}$ in sediments with water contents ranging from $2.0 \mathrm{wt} \%$ to $13.0 \mathrm{wt} \%$. Because high gas-phase ammonia concentrations are present behind the ammonia advection front, diffusion into lower permeability or higher water content zones that are bypassed by advective flows may reach centimeters scale within tens to hundreds of hours of ammonia gas delivery. This may be a sufficient treatment for small features such as silt lenses.

The high $\mathrm{pH}$ induced by ammonia gas partitioning into pore water causes dissolution of minerals and formation of precipitates such as aluminiosilicates and other compounds that can reduce the leachability of contaminants. This process was demonstrated herein and has been studied in additional detail for treatment of uranium by Szecsody et al. [6, 7, 5]. Other contaminants influenced by alkaline conditions in saturated or unsaturated sediments include chromium [31] and technetium [32], where ferrous iron released from mineral dissolution also participates in the contaminant immobilization. For instance, reduction of technetium was found to be necessary to decrease leachability because the dissolution and subsequent precipitation produced through alkaline conditions can only effectively sequester surface phases of technetium 
and is less effective for soluble species like pertechnetate[8]. These results suggest that ammonia treatment may be effective for a range of inorganic contaminants in unsaturated sediments, depending on their behavior under the alkaline conditions and subsequent neutralization that occur from ammonia treatment.

\section{Acknowledgements}

This manuscript was prepared by the Deep Vadose Zone-Applied Field Research Initiative at Pacific Northwest National Laboratory. The research was partially funded by the U.S. Department of Energy (DOE) Richland Operations Office. Additional funds for the research wereprovided by the $\mathrm{CH} 2 \mathrm{M}$ Hill Plateau Remediation Company as part of the Deep Vadose Zone Treatability Test activities for the Hanford Central Plateau. The Pacific Northwest National Laboratory is operated by Battelle Memorial Institute for the DOE under Contract DE-AC05-76RL01830.

\section{References}

[1] Dresel PE, DM Wellman, KJ Cantrell, and MJ Truex. 2011. "Review: Technical and Policy Challenges in Deep Vadose Zone Remediation of Metals and Radionuclides." Environ. Sci. Technol. 45:4207-4216.

[2] Zhong, L., N.P. Qafoku, J.E. Szecsody, P.E. Dresel, and Z.F. Zhang. 2009. Foam Delivery of Calcium Polysulfide to Vadose Zone for Cr(VI) Immobilization - Laboratory Evaluation. The Vadose Zone Journal.Vol. 8, No.4. DOI:10.2136/vzj2008.0124.

[3] Zhong, L., J. Szecsody, M. Oostrom, M. Truex, X. Shen, X. Li. 2011. Enhanced remedial amendment delivery to subsurface using shear thinning fluid and aqueous foam. J. Hazard. Mater. 191: 249-257. 
[4] Denham, ME and BB Looney. 2007. Gas: A Neglected Phase in Remediation of Metals and Radionuclides. Environ. Sci. Technol. 41:4193-4198.

[5] Szecsody, JE; Truex, MJ; Zhong, L; Johnson, TC; Qafoku, N; Williams, MD; Greenwood, J; Wallin, EL; Bargar, JR; Faurie, DK. 2012. Geochemical and Geophysical Changes During NH3 Gas Treatment of Vadose Zone Sediments for Uranium Remediation. The Vadose Zone Journal. Vol. 11 Issue: 4. DOI: 10.2136/vzj2011.0158.

[6] Szecsody JE, MJ Truex, L Zhong, NP Qafoku, MD Williams, JP McKinley, CT Resch, JL Phillips, D Faurie, and J Bargar. 2010a. Remediation of Uranium in the Hanford Vadose Zone Using Ammonia Gas: FY10 Laboratory-Scale Experiments. PNNL-20004, Pacific Northwest National Laboratory, Richland, Washington.

[7] Szecsody JE, MJ Truex, L Zhong, MD Williams, and CT Resch. 2010b. Remediation of Uranium in the Hanford Vadose Zone Using Gas-Transported Reactants: Laboratory-Scale Experiments. PNNL-18879, Pacific Northwest National Laboratory, Richland, Washington.

[8] Szecsody JE, MJ. Truex, L Zhong, JP. McKinley, SD. Saurey. 2014. Remediation of Technetium in Vadose Zone Sediments Using Reactive Gasses $\mathrm{NH}_{3}$ and $\mathrm{H}_{2} \mathrm{~S}$. The Vadose Zone Journal.In revision.

[9] Qafoku, N., CC Ainsworth, JE Szecsody, and OS Qafoku. 2003. Effect of coupled dissolution and redox reactions on $\mathrm{Cr}(\mathrm{VI})$ aq attenuation during transport in the sediments under hyperalkaline conditions. Environ. Sci. Technol. 37: 3640-3646.

[10] Szecsody JE, MJ Truex, N Qafoku, DM Wellman, T Resch, and L Zhong. 2013. Influence of acidic and alkaline waste solution properties on uranium migration in subsurface sediments. J. of Contaminant Hydrology 151:155-175.

[11] Maher, K., D. J. DePaolo, M. E. Conrad, and R. J. Serne. 2003. Vadose zone infiltration rate at Hanford, Washington, inferred from Sr isotope measurements. Water Resour. Res. 39, 1204, doi:10.1029/2002WR001742.

[12] Ma R., C Liu, J Greskowiak, H Prommer, J Zachara, C Zheng. 2014. Influence of calcite on uranium(VI) reactive transport in the groundwater-river mixing zone. J. Contaminant Hydrology. 156: 27-37

[13] Wellman D.M., J.M. Zachara, C. Liu, N.P. Qafoku, S.C. Smith, and S.W. Forrester. 2008. Advective Desorption of Uranium(VI) from Contaminated Hanford Vadose Zone Sediments Under Saturated and Unsaturated Conditions. The Vadose Zone Journal. 7:1144-1159. 
[14] Brina, R., and A. Miller. 1992. Direct detection of trace levels of uranium by laser-induced kinetic phosphorimetry. Analytical Chemistry Spectroscopy, 8:1-14.

[15] White, M.D., and M. Oostrom. 2000. STOMP Subsurface Transport Over Multiple Phases: Theory Guide PNNL-12030 (UC-2010), Pacific Northwest National Laboratory, Richland, Washington.

[16] Spiller L.L. 1989. Determination of Ammonia/Air Diffusion Coefficient using Nafion Lined Tube. Analytical Letters, 22:2561-2573.

[17] Picioreanu, C., van Loosdrecht, M. C. M. \&Heijnen, J. J. (1997). Modelling the effect of oxygen concentration on nitrite accumulation in a biofilm airlift suspension reactor. Water Sci. Technol. 36:147-156.

[18] Millington, R.J., and J.M. Quirk, 1961, Permeability of porous solids. Trans. Faraday Soc., 57:1200-1207.

[19] Chou, H., L. Wu, L. Zeng, and A. Chang. 2012. Evaluation of solute diffusion tortuosity factor models for variously saturated soils, Water Resour. Res. 48, W10539, doi:10.1029/2011WR011653.

[20] Mullins, G. L., and L. E. Sommers (1986), Characterization of cadmium and zinc in four soils treated with sewage-sludge. J. Environ. Qual., 15: 382-387.

[21] Renard, J. J., Calidonna, S. E., \& Henley, M. V. 2004. Fate of ammonia in the atmosphere a review for applicability to hazardous releases. J. Hazardous Materials, 108:29-60.

[22] Clegg, S. L., Whitfield, M. 1995. A Chemical-Model of Seawater Including Dissolved Ammonia and the Stoichiometric Dissociation-Constant of Ammonia in Estuarine Water and Seawater from -2-Degrees-C to 40-Degrees-C. Geochim.Cosmo.Acta. 59, 2403-2421.

[23] Truex MJ, TC Johnson, CE Strickland, JE Peterson, and SS Hubbard. 2013. Monitoring Vadose Zone Desiccation with Geophysical Methods. The Vadose Zone Journal.12. doi:10.2136/vzj2012.0147.

[24] Bloch, M., and W. Luecke. 1970. The origin of fixed nitrogen in the atmosphere. Isr. J. Earth Sci. 19:41-49.

[25] Brimblecombe, P., and Dawson G.A. 1984. "Wet removal of highly soluble gases". J. of Atmospheric Chemistry, 2:95-107.

[26] Oostrom, M., T. W. Wietsma, J. H. Dane, M. J. Truex and A. L. Ward. 2009. Desiccation of Unsaturated Porous Media: Intermediate-Scale Experiments and Numerical Simulation. The Vadose Zone Journal. 8:643-650. 
[27] Barnes, M. C, Addai-Mensah, J., Gerson, R. R. 1999. The solubility of sodalite and cancrinite in synthetic spent Bayer liquor. Colloids Surf. A. 157:101-116.

[28] Zhao H.T., Y.J. Deng, J.B. Harsh, M. Flury and J.S. Boyle. 2004. Alteration of kaolinite to cancrinite and sodalite by simulated Hanford tank waste and its impact on cesium retention. Clays Clay Min. 52:1-13.

[29] Wan, J.M., Larsen, J.T., Tokunaga, T.K., Zheng, Z.P., 2004. pH neutralization and zonation in alkaline-saline tank waste plumes. Environ. Sci. Technol. 38:1321-1329.

[30] Davis, M., Wesolowski, D., Rosenqvist, J., Brantley, S., and K. Mueller, Solubility and near-equilibrium dissolution rates of quartz in dilute $\mathrm{NaCl}$ solutions at $398-473 \mathrm{~K}$ under alkaline conditions. Geochim.Cosmo.Acta. 75, 401-415.

[31] Zachara J., C. Ainsworth, G Brown, J. Catalano, J. McKinley, O. Qafoku, S. Smith, J. Szecsody, S. Traina, and J. Warner. 2004. Chromium speciation and mobility in a high level nuclear waste vadose zone plume. Geochim.Cosmo.Acta. 68:13-30.

[32] Szecsody JE, D Jansik, JP McKinley, and N Hess. 2014. Influence of alkaline waste on technetium mobility in Hanford formation sediments. J. Environ. Radioac. 135:147-160.

Figures And Tables:

Figure 1. Overview of the processes that occur with injection of ammonia vapor into anunsaturated, uranium-contaminated sediment.

Figure 2. Sediment packing patterns applied in 2D NH3diffusion experiments.

Figure 3. Calculated equilibrium gas/liquid ammonia gas partitioning into sediment pore water.

Figure 4. Plot of the $\mathrm{pH}$ obtained experimentally by bubbling $\mathrm{NH} 3$ gas at concentration from $0.1 \%$ to $100 \% \mathrm{v} / \mathrm{v}$ into $100 \mathrm{mLdeionized} \mathrm{water} \mathrm{at} \mathrm{flow} \mathrm{rate} \mathrm{of} 20 \mathrm{~mL} / \mathrm{min}$. for $10 \mathrm{~min}$., compared to the calculated equilibrium $\mathrm{pH}$ for ammonia gas partitioning into DIW.

Figure 5. Plot of $\mathrm{pH}$ profile resulting from $5 \% \mathrm{v} / \mathrm{v} \mathrm{NH} 3$ gas injection into $610 \mathrm{~cm}(20 \mathrm{ft}$ ) long columns at different injection flow rates. The injection durations were 230,640 , and $110 \mathrm{~min}$. for injection flow rates of $11.3,127$, and $953 \mathrm{~cm} / \mathrm{min}$. , respectively 
Figure 6.Changes in sediment temperature over time at specific axial distances from the inlet of a $9.1 \mathrm{~m}$ (30 ft) long sediment column during $100 \% \mathrm{NH} 3$ gas injection. The spike in temperature indicates the arrival of the NH3 gas front.The inlet temperature ends up dropping below the initial temperature due to water evaporation, caused by desiccation of near-inlet sediments during the test.

Figure 7. Location of $\mathrm{NH} 3$ diffusion front ( $0.1 \mathrm{M}$ concentration in pore water) in sediment columns versus time. Sediment column groups G1, G2, and G3 have water contents of $2 \%, 8.7 \%$, and $13 w t \%$, respectively. The dotted lines are linear fits to the experimental data, with the corresponding fitting equations presented. The solid lines are the STOMP simulation results.

Figure 8.Dissolved NH3 distribution in heterogeneous systems for(a) Pack 2D-P1 and (b)Pack 2D-P2. The inlets are at the top and center of the packs. The gaps at the depths where no samples were taken.

Figure 9.NH3 injection into a radial flow system containing continuous layers and lenses of heterogeneity $(a, b)$; the reaction front (the cloudy zone) is shown at four time intervals (c); and a close up of water droplets inside the flow cell wall (d). At 5 and 6.5 hours, desiccation was shown at the inlet.

Figure 10. Profile of pore water $\mathrm{pH}$ in wedge sediments (a) and $\mathrm{pH}$ change over time when sediment was exposed to air (b). In (a), the ammonia gas treatment PV for differing distance from the inlet are included.The PV is calculated based on the total injected $\mathrm{NH} 3$ volume and the pore volume in the wedge section from the inlet to the corresponding distance.

Figure 11.Sediment pore water cation concentration changes over time during $10 \% \mathrm{NH} 3$ batch treatment of sand sediments(a-f). The $\mathrm{pH}$ change over the treatment period is presented in (g). The untreated sediment had a water content of $1 \mathrm{wt} \%$.

Figure 12.Pore water ion concentrations in sediments at differing distances in a $6.0 \mathrm{~m}(20-\mathrm{ft})$ column after NH3 injection. The associated NH3 treatment PV is labeled to each sample. The PV is calculated based on the total injected gas mixture volume and the pore volume in the column section from the inlet to the sample location.

Figure 13. Mass of uranium leached from NH3-treated sediment compared with untreated sediment. After ammonia treatment, the sediment was flushed with air and set undisturbed for 26000 hours (about 3 years).

Table 1. Sediment grain size and mineralogy characterization

\begin{tabular}{|l|l|l|}
\hline Sample Location & $\begin{array}{l}\text { Hanford Formation } \\
\text { sand }\end{array}$ & $\begin{array}{l}\text { Cold Creek unit } \\
\text { silty sand }{ }^{a}\end{array}$ \\
\hline Depth $(\mathrm{m})$ & 6.1 & 45 \\
\hline
\end{tabular}




\begin{tabular}{|l|l|l|l|}
\hline \multirow{4}{*}{ Grain Size } & gravel, sand (\%) & 94.8 & 63.9 \\
\cline { 2 - 4 } & silt (\%) & 3.8 & \multirow{2}{*}{36.1} \\
\cline { 2 - 4 } & clay (\%) & 1.4 & \\
\hline \multirow{4}{*}{$\begin{array}{l}\text { Mineralogy } \\
\text { (for the }<2 \mathrm{~mm} \\
\text { particle size } \\
\text { fraction) }\end{array}$} & quartz (\%) & 34 & 52 \\
\cline { 2 - 4 } & plagioclase & 27 & 25 \\
\cline { 2 - 4 } & mica & 17 & - \\
\cline { 2 - 4 } & K-feldspar & 13 & - \\
\cline { 2 - 4 } & amphibole & 6 & - \\
\cline { 2 - 4 } & chlorite & 4 & \\
\cline { 2 - 4 } & calcite & - & \\
\hline
\end{tabular}

Silty sand data from reference[11].

Table 2.Ammonia gas partitioning into water and the resulting $\mathrm{pH}$.

\begin{tabular}{lll}
\hline$\% \mathrm{NH}_{3(\mathrm{~g})}$ & {$\left[\mathrm{NH}_{3}\right]_{\text {(a) }) \text { total }}(\mathrm{M})$} & $\mathrm{pH}$ \\
$\mathbf{1 0 0}$ & 15.7 & 12.52 \\
$\mathbf{3 0}$ & 9.2 & 12.26 \\
$\mathbf{1 0}$ & 6.3 & 12.02 \\
$\mathbf{5}$ & 3.1 & 11.87 \\
$\mathbf{1}$ & 0.63 & 11.52 \\
$\mathbf{0 . 3}$ & 0.19 & 11.26 \\
$\mathbf{0 . 1}$ & $6.3 \times 10^{-2}$ & 11.02 \\
$\mathbf{0 . 0 1}$ & $6.3 \times 10^{-3}$ & 10.51 \\
$\mathbf{1 0}$ & $6.3 \times 10^{-4}$ & 9.99 \\
$\mathbf{1 0}$ & $6.3 \times 10^{-5}$ & 9.41 \\
$\mathbf{1 0}$ & $6.3 \times 10^{-5}$ & 8.69 \\
$\mathbf{1 0}$ & $6.3 \times 10^{-6}$ & 7.78 \\
\hline
\end{tabular}




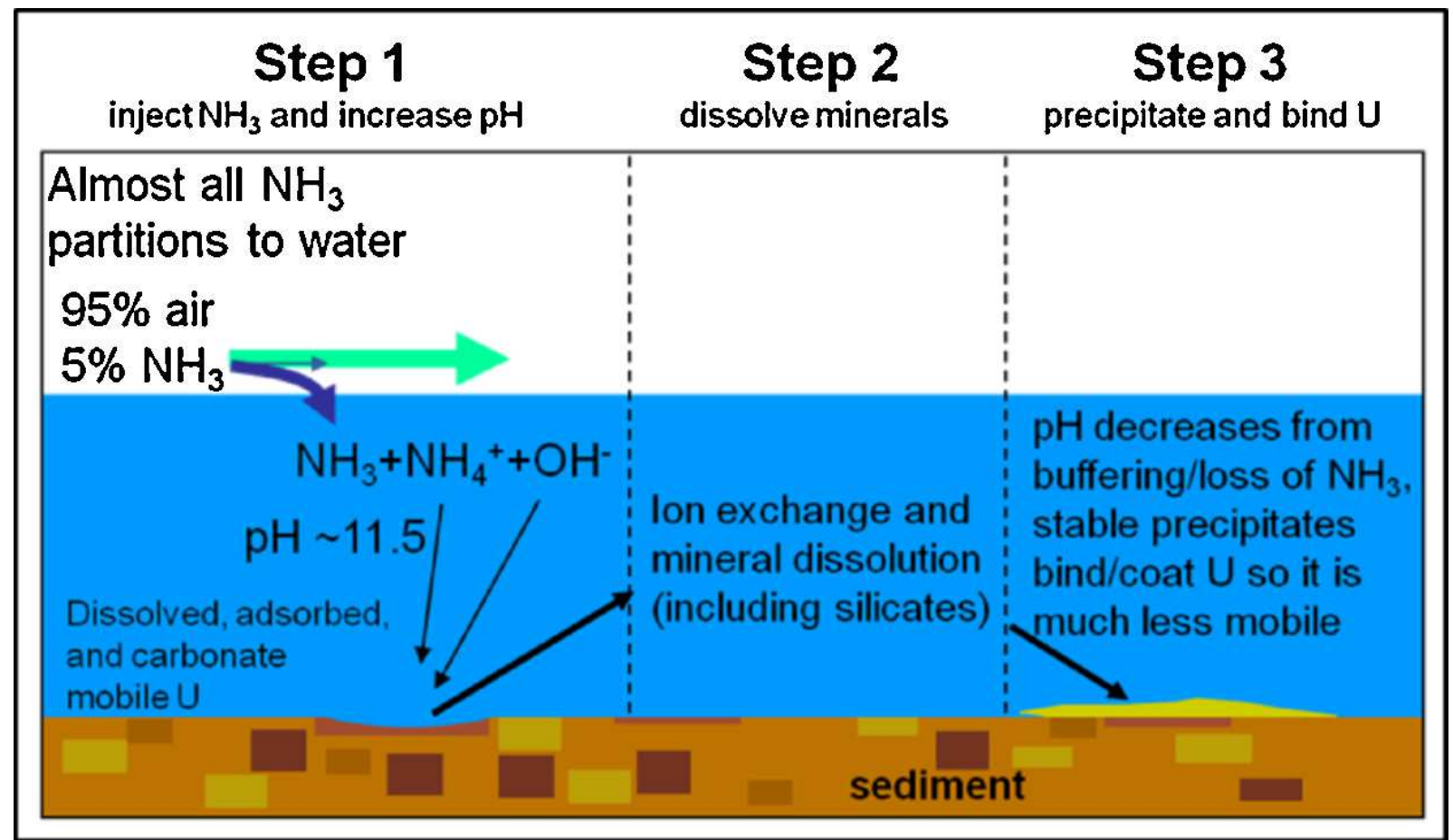

gr1. 

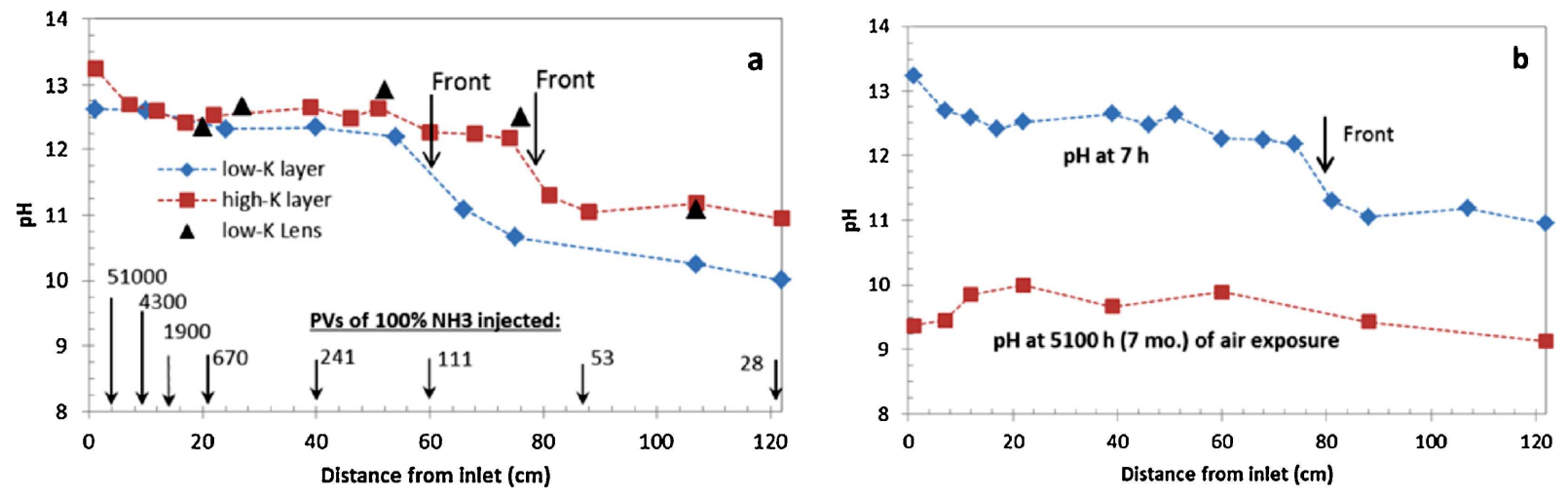

gr10 . 

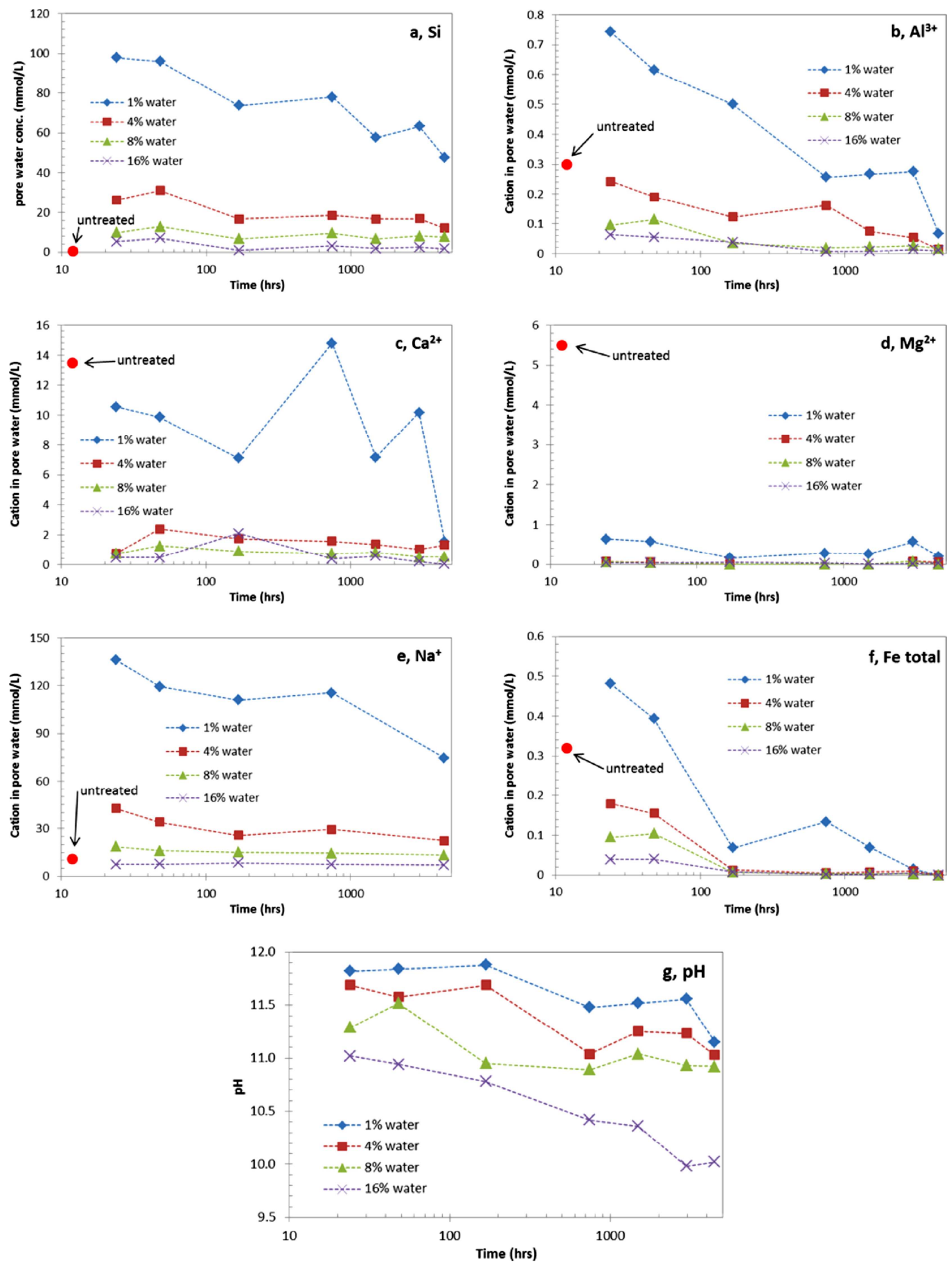
gr11. 

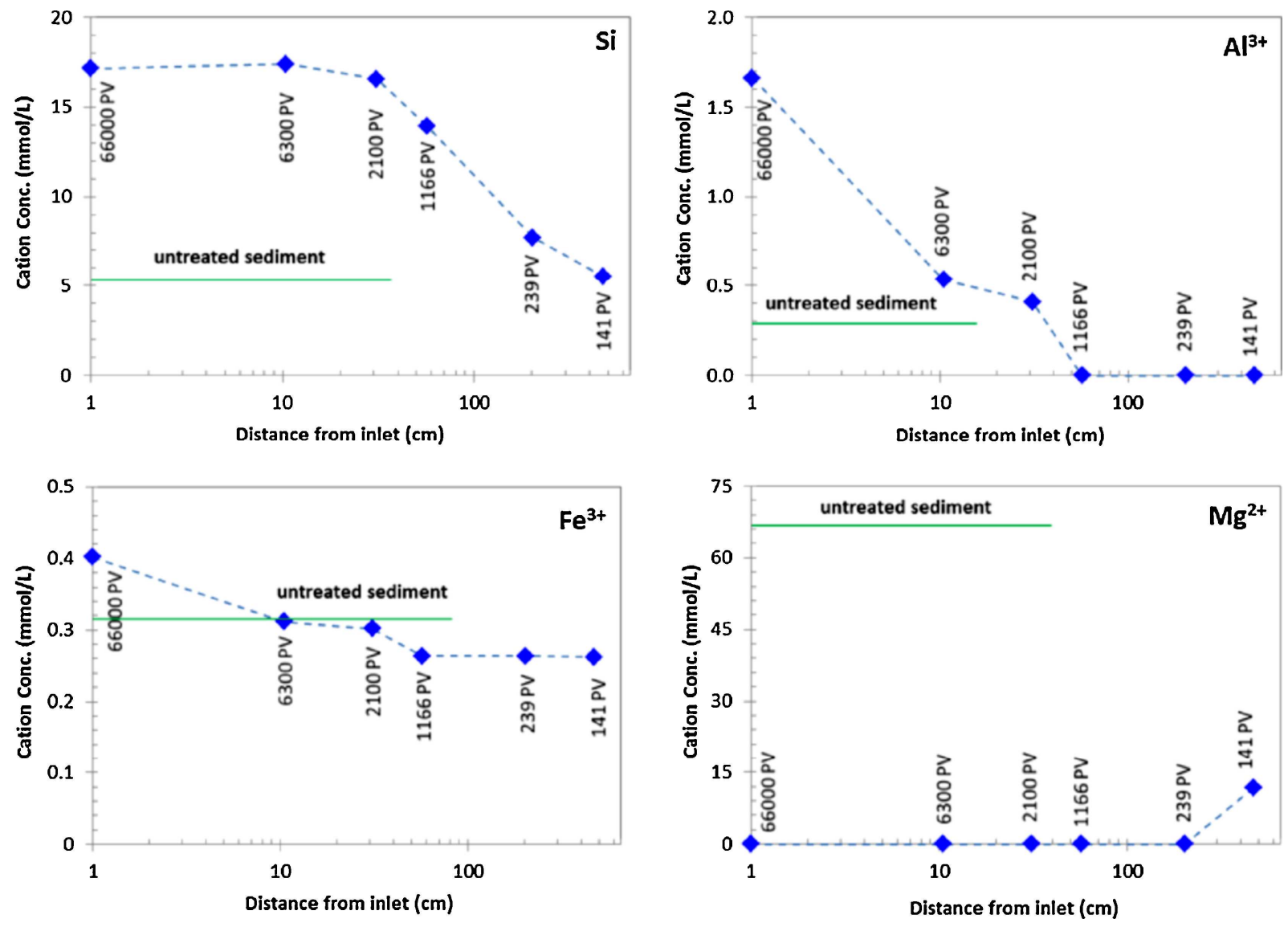

gr12. 


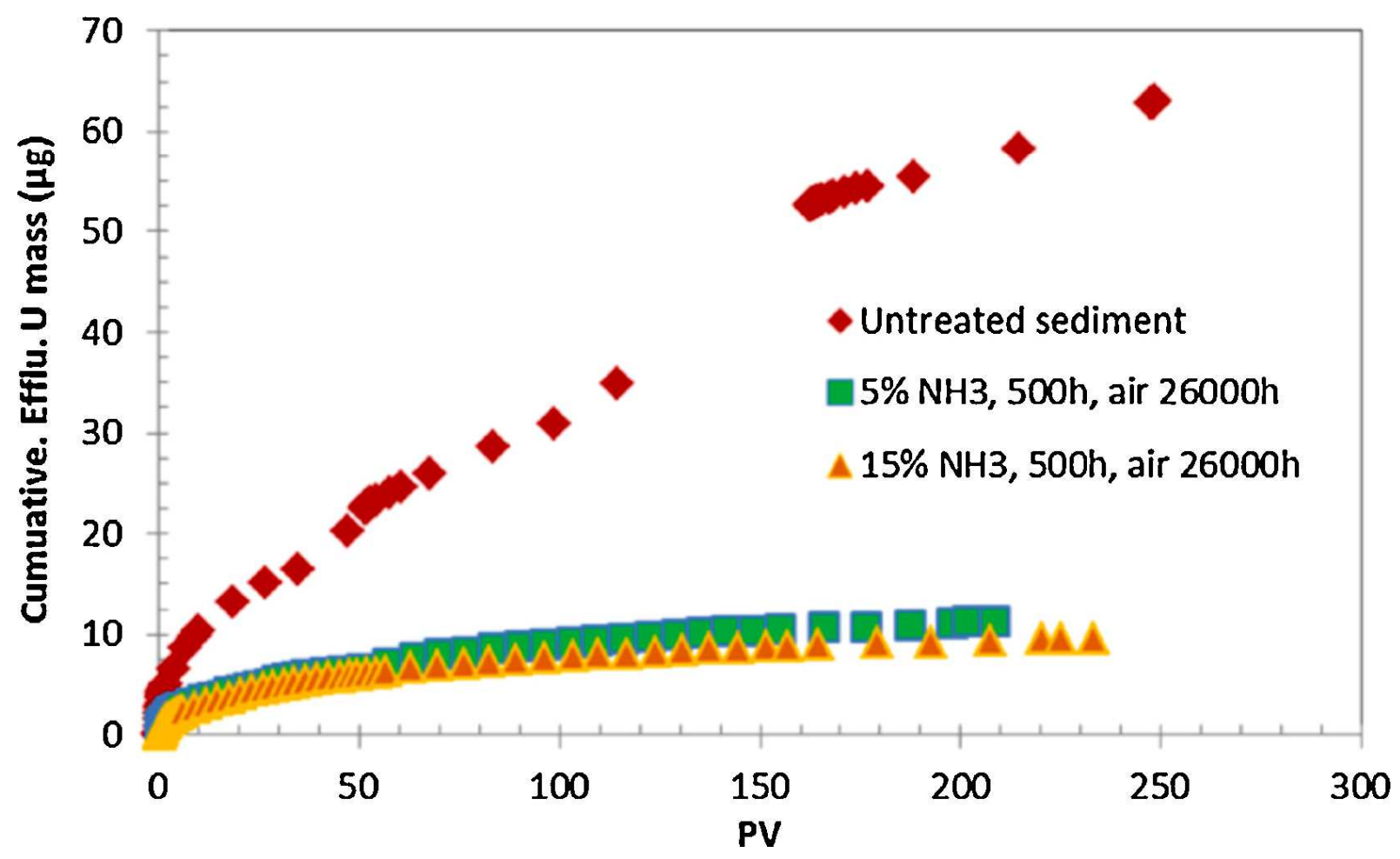

gr13. 

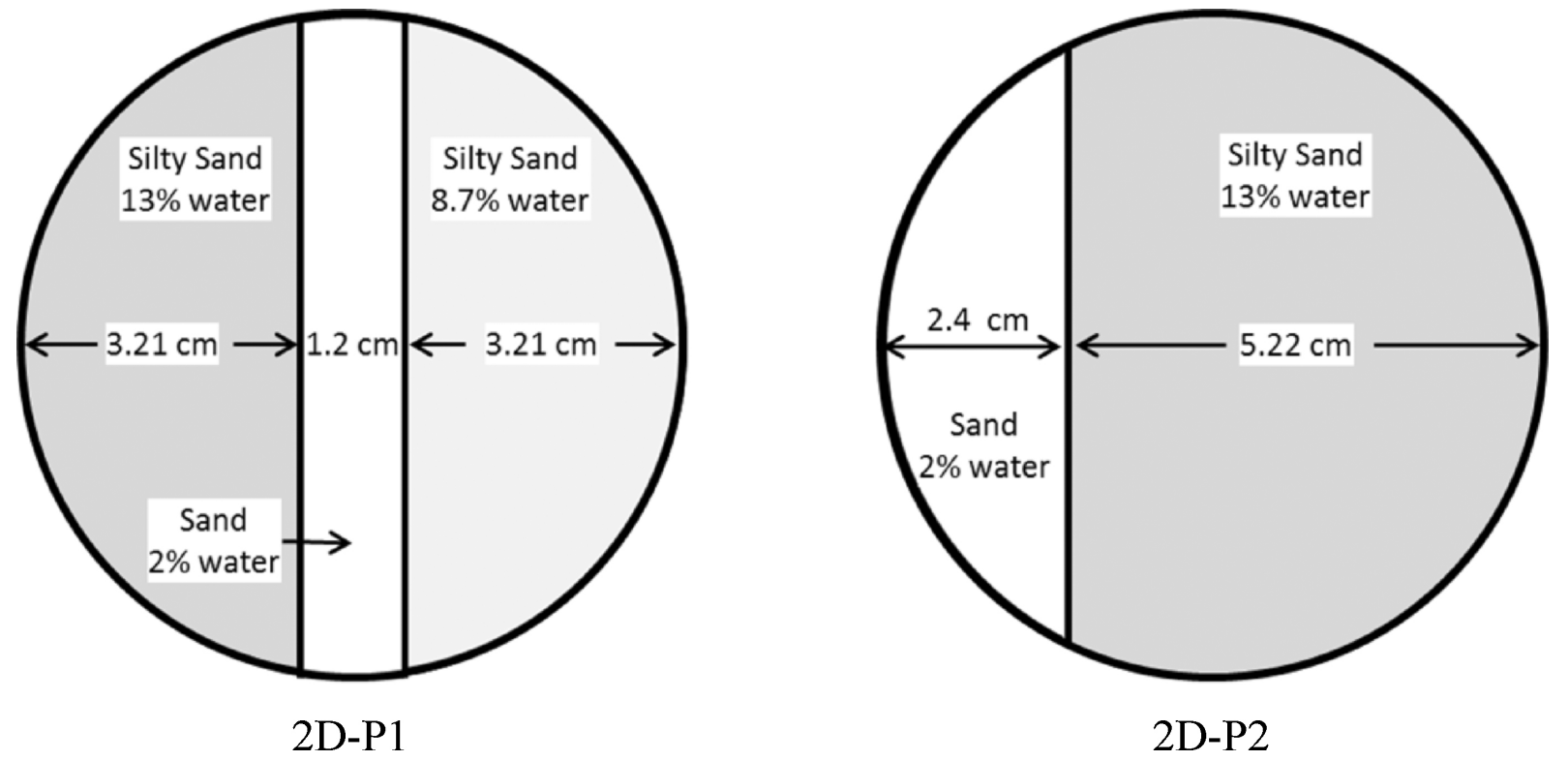

gr2. 


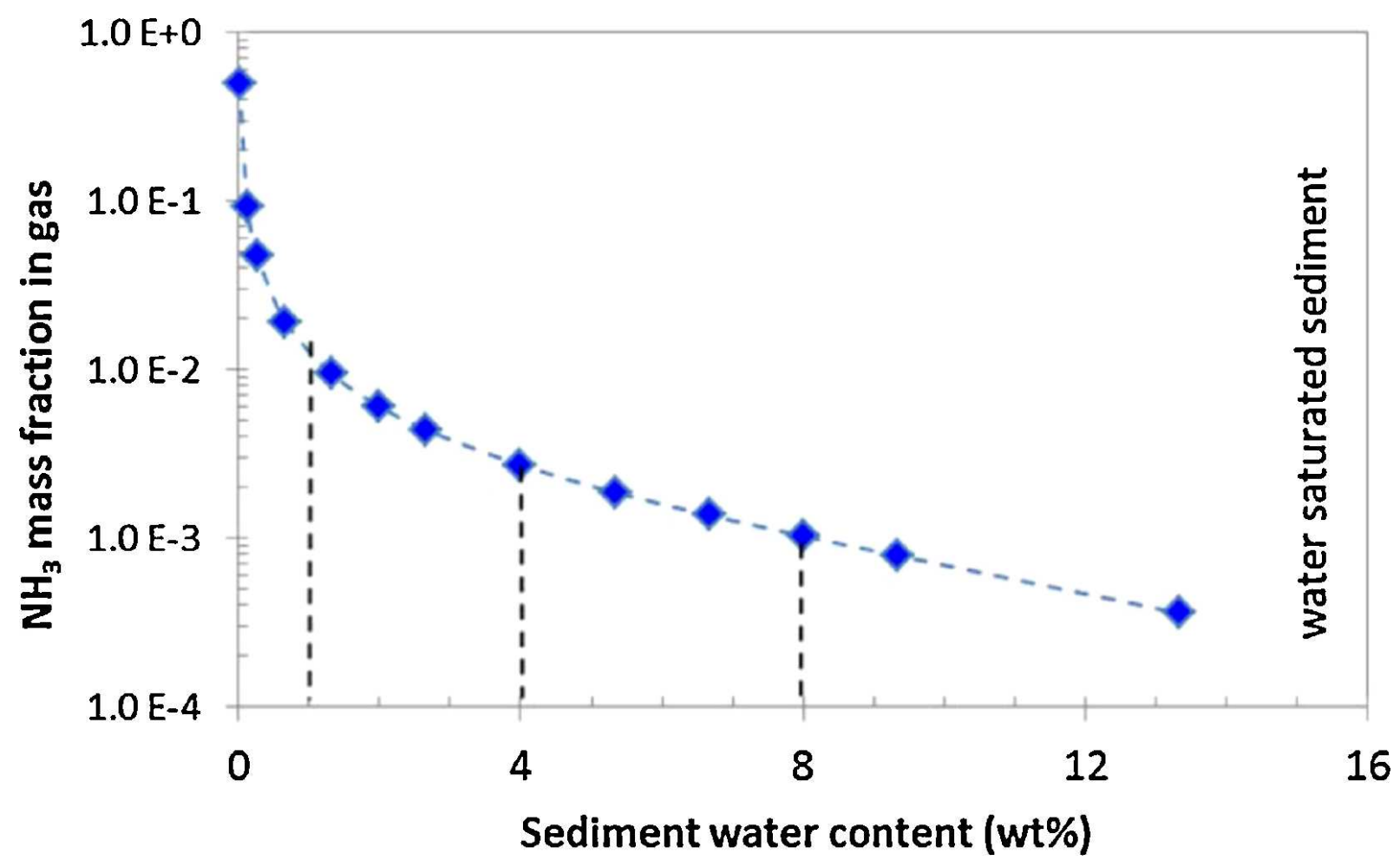

gr3. 


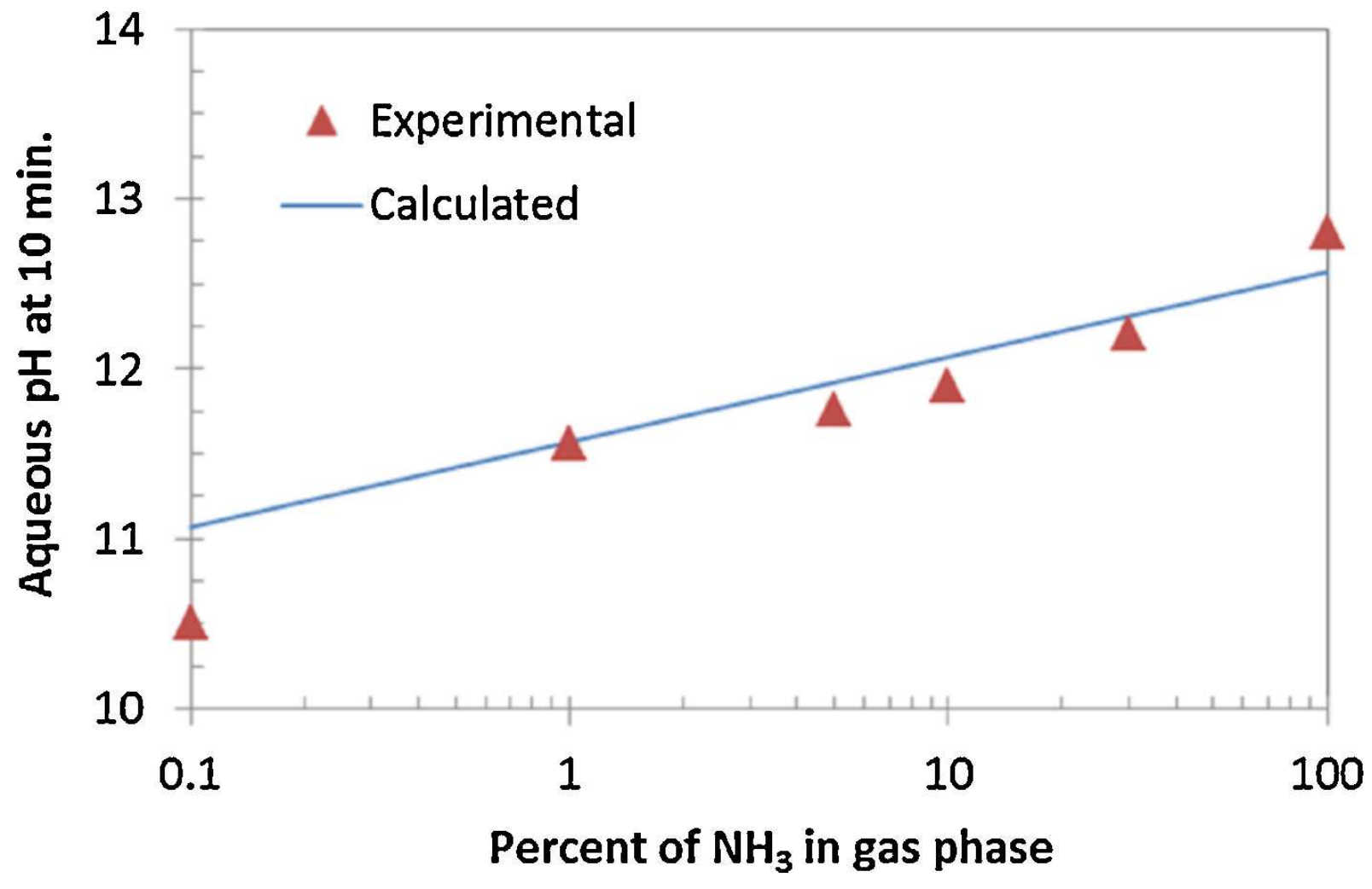

gr4 . 


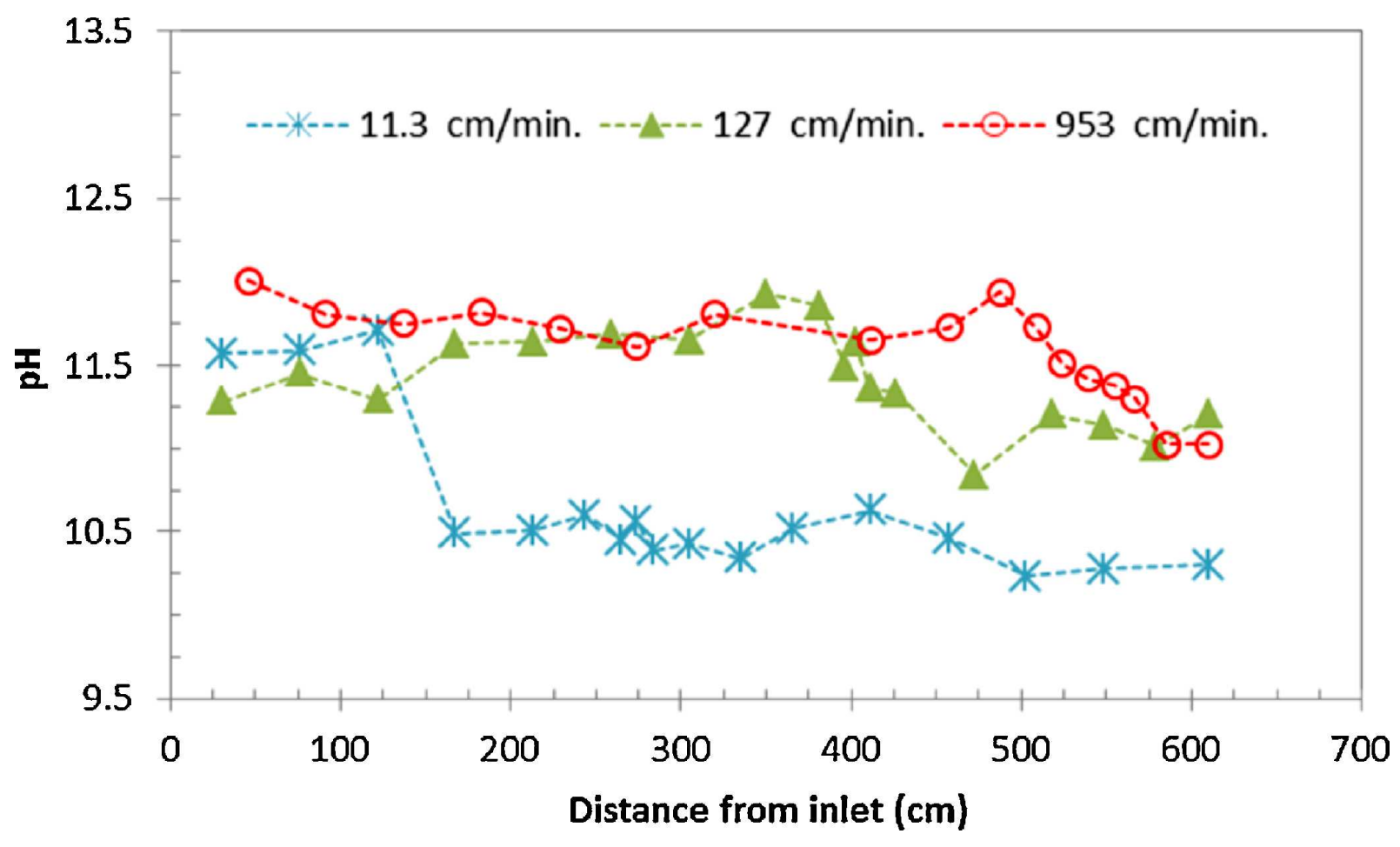

gr5 . 


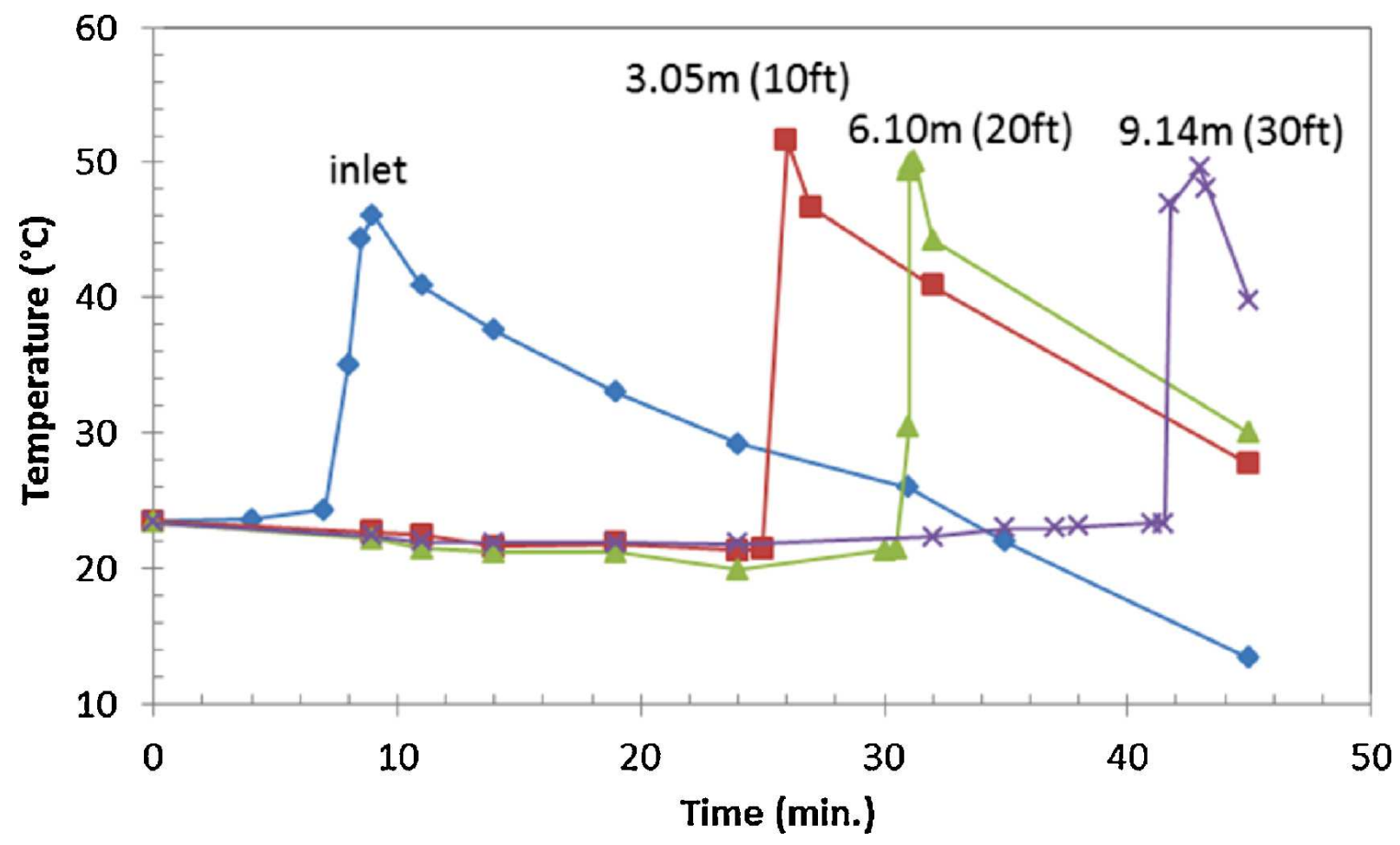

gr6 . 


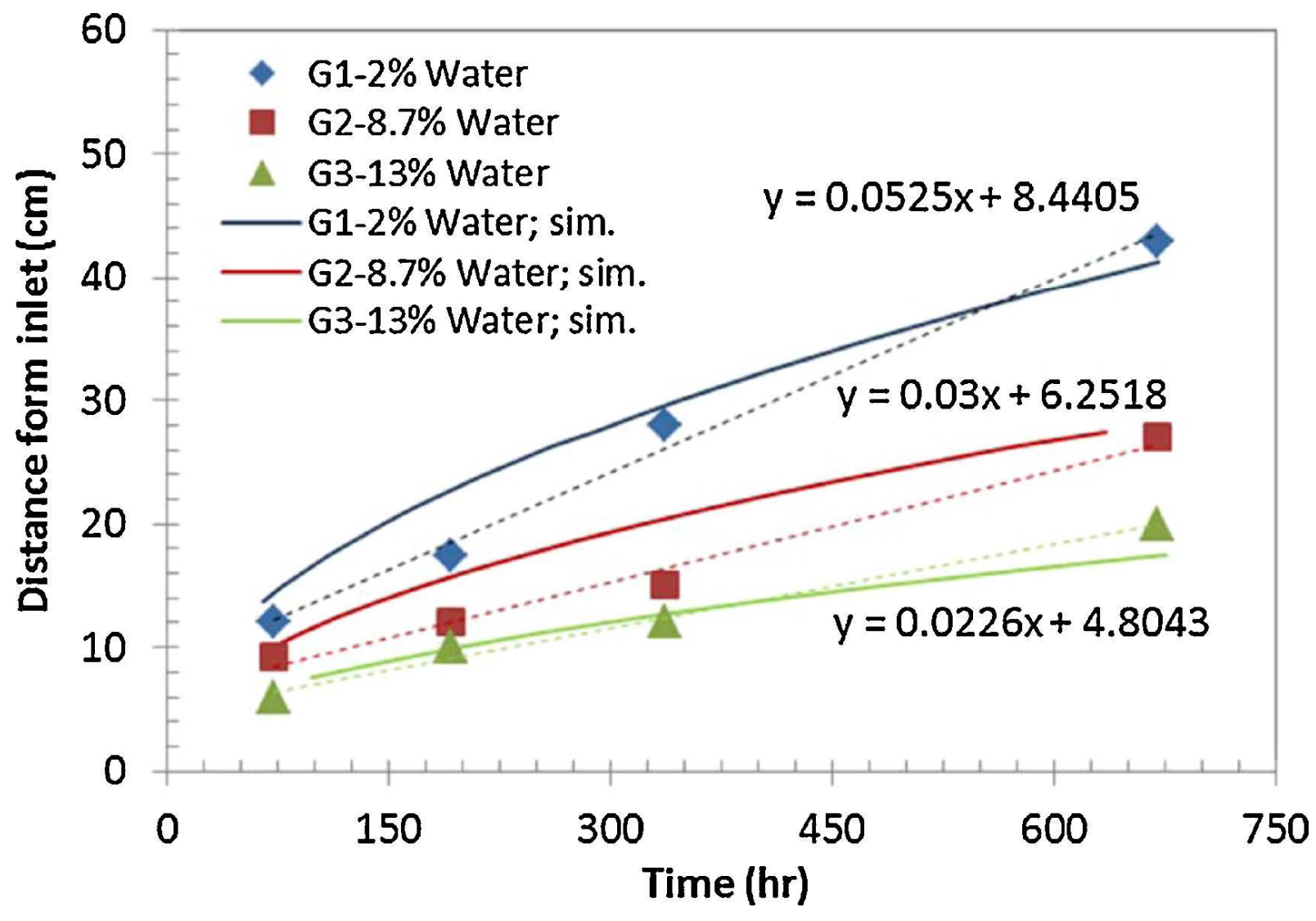

gr7. 

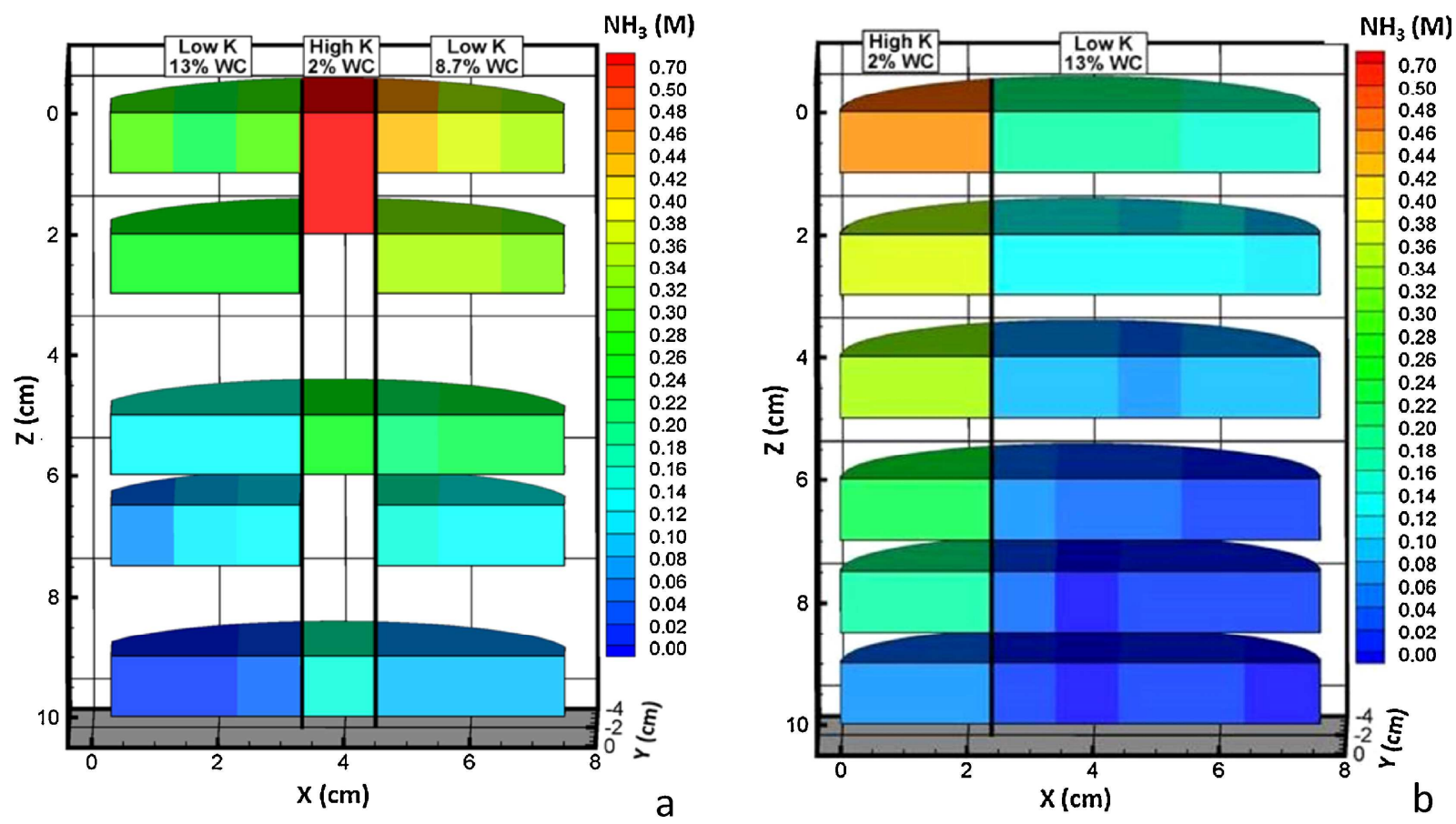

gr8 . 

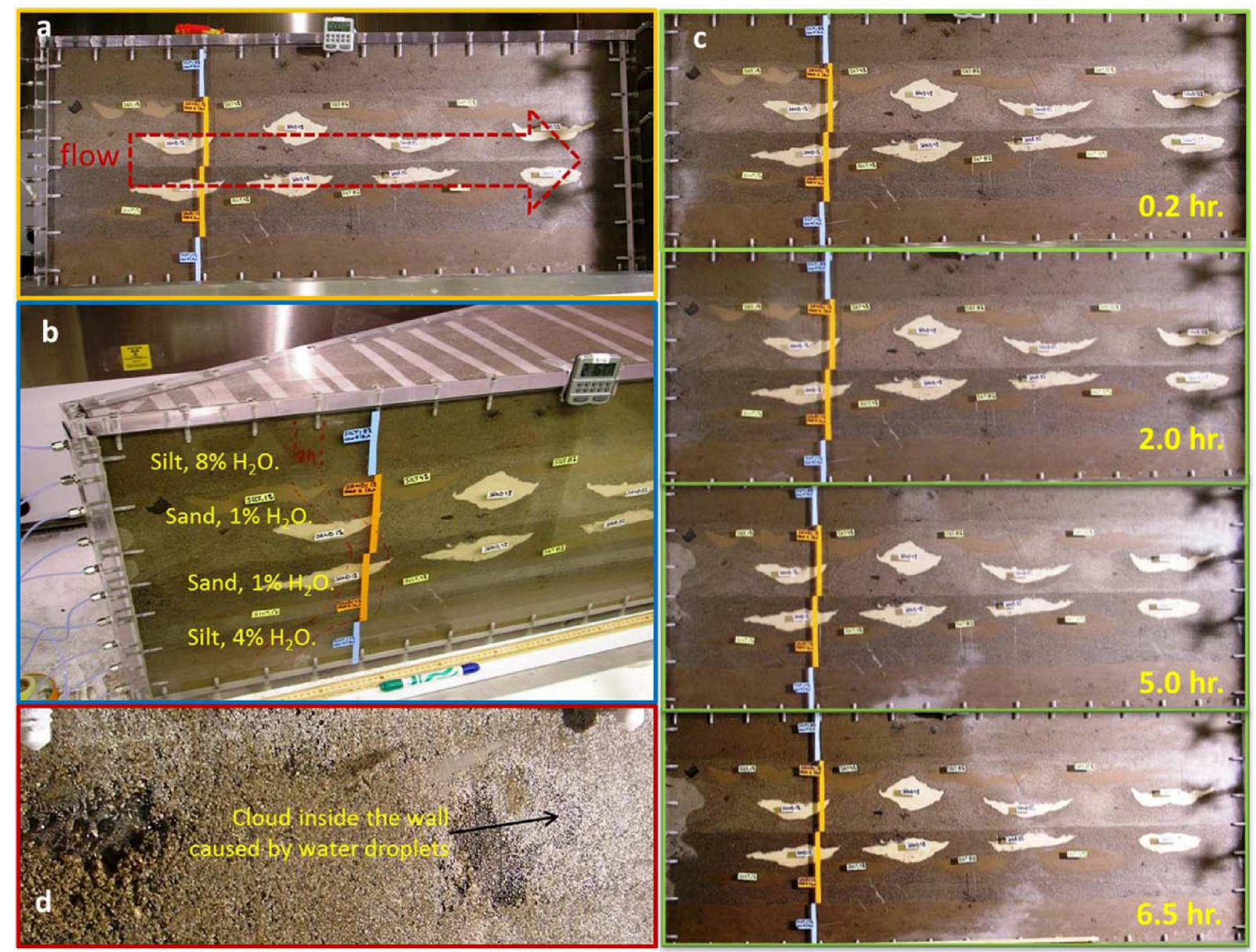

gr9 . 